\title{
Location, location, location! \\ Real effects from the mandated removal of pension expected return from operating income
}

\author{
Divya Anantharaman \\ Associate Professor \\ Rutgers Business School \\ 1 Washington Park Room 916 \\ Newark, NJ 07102 \\ divyaa@rutgers.edu \\ Elizabeth Chuk \\ Associate Professor \\ University of California, Irvine \\ 4293 Pereira Drive SB2 413 \\ Irvine, CA 92697 \\ elizchuk@uci.edu \\ Saipriya Kamath* \\ Assistant Professor \\ London School of Economics \\ Houghton Street, London \\ s.kamath2@1se.ac.uk
}

February 19, 2021

The accounting for defined-benefit (DB) pension expense in U.S. GAAP involves offsetting pension costs against an expected (rather than actual) return on pension assets. Pensions commentators argue that this expensing model tilts pension portfolios towards riskier assets as sponsoring firms can benefit from assuming higher expected rates of return on riskier assets (which reduce pension expense and boost reported income), without bearing the cost of higher volatility in reported income. We examine a recent regulatory change in U.S. GAAP, which mandates the relocation of the expected return on pension assets from "above the line" of to "below the line" of operating income. Consistent with this change reducing the financial reporting incentives for risk-taking, we predict and find that a sample of U.S. firms subject to this mandate reduces risk-taking in pension assets following the change, relative to a control sample of Canadian firms not subject to the change. In cross-sectional tests, we find that the reduction in risk-taking is more pronounced in (1) firms where the financial reporting incentives for risk-taking were stronger in the pre-period, and in (2) firms where the regulatory change particularly reduced those benefits. Our findings imply that managers are willing to undertake real actions (i.e., invest in riskier assets) to report favorable operating income, and that these incentives are incremental to the incentives to report favorable net income. They also provide evidence that financial reporting incentives serve as a driver of pension asset allocation decisions.

Keywords: Accounting regulation, standard-setting, defined benefit pension, operating income, Accounting Standards Update No. 2017-07

JEL Codes: M40, M41, M48

*Corresponding author. We are grateful for feedback from brown bag participants at LSE. Prateek Kansal and Arya Farazdaghi provided excellent research assistance. Comments are welcome. All errors are our own. 


\section{INTRODUCTION}

The accounting model for defined-benefit (DB) pension expense is extremely controversial. Under current U.S. GAAP, pension expense on the sponsoring firm's income statement is determined by offsetting the income-decreasing components of pension expense (service costs and interest costs, among others) by the return on assets in the pension plan's asset portfolio. However, pension costs are not offset by the actual returns earned by pension assets over the fiscal period; they are instead offset by expected return on pension assets, determined by multiplying the fair value of pension assets with a long-term expected rate of return (ERR) assumption chosen by managers. This "smoothing" of pension expense through the use of an expected (rather than actual) return has invited many criticisms; for one, that it invites unrealistic ERR assumptions to boost reported net income. ${ }^{1}$ For another, that it biases pension portfolios towards riskier investments such as equities - as sponsors can then reap the income statement benefits of a higher ERR (which reduces pension expense, and boosts reported income) without the offsetting costs of higher volatility in pension expense. ${ }^{2}$ Academic evidence indirectly supports this contention of a "real effect" to ERR-based pension expense (Bergstresser, Desai, and Rauh 2006, Chuk 2013).

A recent move from the Financial Accounting Standards Board ("FASB") has the potential to dampen these financial reporting incentives to tilt towards riskier investments. Accounting Standards Update 2017-07 (hereafter, “ASU 2017-07”) 3 alters the presentation of pension expense on the income statement, while keeping its measurement unchanged.

\footnotetext{
${ }^{1}$ Warren Buffet, in his 2007 Letter to Shareholders, famously quipped: "What is no puzzle, however, is why CEOs opt for a high investment assumption. It lets them report higher earnings. And if they are wrong, as I believe they are, the chickens won't come home to roost until long after they retire." Available at: https://www.berkshirehathaway.com/letters/2007ltr.pdf

${ }^{2}$ Gold (2005), in an influential piece titled "Accounting/Actuarial Bias Enables Equity Investment by Defined Benefit Pension Plans" summarizes the income statement benefits of the ERR model thus: "corporate financial officers enjoy the benefit of the equity premium while avoiding much of the concomitant risk". This view has been subsequently echoed by many, such as Frieman et al. (2005), describing the smoothing model as an "opaque method of accounting that highlights the rewards of equity but obscures its risks".

${ }^{3}$ Accounting Standards Update 2017-07 Compensation-Retirement Benefits (Topic 715): Improving the

Presentation of Net Periodic Pension Cost and Net Periodic Postretirement Benefit Cost (FASB 2017).
} 
Specifically, it mandates the removal of all components of pension expense other than service cost e.g., interest cost, expected return on plan assets, amortization of actuarial gains/losses and prior service costs, from operating income to net income. Of particular interest is the expected return component, which still flows positively into net income but no longer flows into operating income (i.e., it moves from "above the line" to "below the line" of operating income). Hence, any risk premium in the ERR (arising from higher investment in risky assets) no longer benefits operating income, only net income. This begs the question: to the extent to which the financial reporting benefits of a higher ERR have declined, will sponsors tilt less towards riskier investments in their pension portfolios? This is the question we seek to answer in this study. We predict that the ASU reduces managers' reporting-based incentives to invest in riskier assets, and expect some "unwinding" of pension risk-taking as a result.

Two conceptual questions about financial statement presentation and its impact on stakeholders and managers underpin our prediction in the pension setting. First, do the financial reporting benefits from a higher ERR indeed decline, as its impact shifts out of operating income solely into net income? Under ASU 2017-07's mandated presentation, a higher ERR presumably backed by higher-risk assets in the pension portfolio - will have the same impact as previously on net income, with the only difference being that it no longer boosts operating income. Therefore, this question boils down to: does operating income matter, incrementally to net income itself? Only if it does - and if managers believe that it does - would their prior incentives to tilt toward equities become lower, at the margin, once operating income no longer directly benefits from that tilt.

There are many reasons to believe that the distinction between operating income (a subtotal on the income statement) and net income (the "bottom line") is nontrivial. A stream of literature suggests that investors perceive line items further-down on the income statement as more transitory (e.g., Lipe 1986; Fairfield, Sweeney, and Yohn 1996); the ASU moves the 
expected return in that very direction. Furthermore, the pervasive use of "proforma" earnings numbers - many of which are conceptually closer to operating income than to net income suggests that performance metrics approximating operating income could be more decisionrelevant than net income. Finally, operating income, in particular, is often used alongside net income in contracting. For these reasons, we predict that managerial behavior will change after ASU 2017-07 in response to the reduced financial reporting importance of the expected return. Despite these factors, the countervailing argument remains that even after ASU 2017-07, the expected return continues to affect net income. A higher ERR can hence still boost net income, an indisputably important summary metric of performance from the standpoints of valuation and contracting. So, whether the ASU's reduction in the financial reporting benefits of a higher ERR are substantial enough to actually induce managers to shift asset allocations, begs empirical examination.

The second conceptual question underpinning our prediction is whether a GAAPmandated re-arrangement of pension cost components on the income statement has the ability to shift beliefs about firm performance sufficiently to induce a response from managers. This question assumes particular importance once we consider the (now, longstanding) practice of proforma or non-GAAP reporting. Re-arranging and/or re-measuring the components of pension expense to compute proforma measures has been prevalent for decades. For example, when computing its own proforma measure of pension cost, Standard \& Poor's removes the expected return component and replaces it with the actual return on pension assets (Standard \& Poor's 2003). ${ }^{4}$ Similarly, Moody's makes a number of adjustments to "eliminate the effects of artificial smoothing of pension expense permitted by accounting standards" (Moody's 2006;

\footnotetext{
${ }^{4}$ Specifically, if actual returns are positive, then actual returns reduce pension expense up to the amount of reported interest expense. If actual returns are negative, the full amount of actual returns is treated as an addition to pension expense.
} 
Moody's 2016). ${ }^{5}$ In fact, in its formulation of ASU 2017-07, the FASB acknowledges that the "separation of the service cost component from the other components is highly supported by financial statement users and is consistent with the adjustment often made by some users in their analyses" (ASU 2017-07, Paragraph BC12).

Therefore, it appears that some financial statement users devote time and resources to re-arranging the components of pension expense, for the purpose of deriving an alternative measure thereof, which is presumably used as a substitute to pension expense reported on the income statement. The long-standing prevalence of such non-GAAP substitutes suggests that the GAAP pension expense was not perceived as useful by at least some users. Against this background, the ASU's mandated rearrangement of pension cost components could simply bring GAAP numbers in line with non-GAAP metrics already computed and used in practice. If the benefits of a higher ERR were already stripped out of operating income by users in the pre-ASU regime, and if managers correctly perceived that, it begs the question of whether the ASU itself will trigger any real response from managers making asset allocation decisions.

We examine our question with a sample of U.S. DB sponsors, which are subject to the ASU, along with to a control sample of Canadian DB sponsors which report under IFRS and are hence not subject to the ASU. Using a difference-in-difference research design and entropy balancing, we find that affected U.S. firms reduce risk-taking in pension assets after the ASU, relative to Canadian firms. While these base findings are supportive of our prediction, we rely on cross-sectional tests to more confidently attribute the reduction in equities to the ASU's reduction of financial reporting benefits from a higher ERR. We motivate cross-sectional tests along two dimensions: (1) firms for which the financial reporting benefits of risk-taking, as

\footnotetext{
${ }^{5}$ In particular, Moody's reverses all pension costs but adds back service cost; attributes interest expense to pension-related debt using an interest rate that represents a theoretical average borrowing cost for each issuer based on its credit rating; recognizes interest cost in other non-recurring income/expense; and adds or subtracts actual losses or gains on pension assets (up to the interest cost) in non-recurring other income/expense.
} 
induced by the ERR-based expensing model, were stronger in the first place (pre-ASU); and (2) firms for which the ASU reduced those financial reporting benefits more significantly.

For our first set of cross-sectional tests, we isolate firms that, pre-ASU, had stronger incentives to invest in risky assets - and were therefore left with more risky positions to "unwind" post-ASU. We operationalize these incentives with: (i) the ratio of the expected return to total pension expense excluding the expected return - i.e., how economically significant the expected return (and hence the ERR assumption) is in offsetting the incomedecreasing components of pension expense, (ii) the ratio of the fair value of pension assets to operating income - i.e., how much will a given change in ERR affect operating income (by virtue of being multiplied by the fair value of pension assets). Consistent with expectation, we find that the reduction in equities is concentrated among firms where the expected return component is economically significant to pension expense and where the ERR is a powerful lever with which to boost reported income.

In our second set of cross-sectional tests, we isolate firms for which the ASU's particular relocation reduced the financial reporting benefits of risk-taking more significantly. Intuitively, we would expect the benefits of boosting the ERR to be particularly affected for those firms for which operating income is more important as a summary metric of performance. Accordingly, we partition on (i) firms for which analysts explicitly forecast operating income, and (ii) firms for which the operating income is more value-relevant relative to net income. We then isolate the significant reduction in equity investments to these groups. Collectively, both sets of cross-sectional tests help us to attribute the reduction in equity allocations to our proposed mechanism: an unwinding of risky investments built up in the pre-ASU period specifically to help justify a higher ERR, which would in turn boost reported operating income.

Our study makes several contributions. First, we contribute to the literature on real effects of accounting, which documents that managers undertake actions with cash flow 
consequences in order to report favorable accounting numbers (Horwitz and Kolodny 1981; Choudhary, Rajgopal, and Venkatachalam 2009; Zhang 2009; Chuk 2013; Anantharaman and Chuk 2018). This literature has focused largely on managerial incentives to report net income; we document evidence consistent with firms having undertaken actions with cash flow consequences (i.e., investing in riskier assets) at least in part to report favorable operating income, while holding constant the incentives to report favorable net income. In other words, we document that operating income matters to managers, incrementally to net income. Finding that managers treat operating income as an important metric is particularly interesting in light of its status - or lack thereof - in GAAP: despite past agenda projects to "consider whether to require the display of summarized amounts such as operating income or income from core activities, EBITDA, or operating cash flows" (FASB 2001, Page 2), to date, "current GAAP has no definition of operating income or lacks guidance on what should be included in operating income" (ASU 2017-07, Paragraph BC21). ${ }^{6}$

Second, we contribute to the literature on location of financial statement line items. One strand of this literature shows that managers exercise discretion in locating various line items on the financial statements (e.g., reporting a loss as part of special items rather than core earnings), often for opportunistic reasons (McVay 2006; Lee, Petroni and Shen 2006; Curtis, McVay, and Whipple 2014; Gordon, Henry, Jorgensen, and Linthicum 2017). Another strand, closer to our own, examines GAAP-mandated changes in the location of specific financial statement line items (e.g., a rule change that relocates early debt extinguishments from extraordinary items to earnings before income taxes, as in Bartov and Mohanram 2014). These studies focus primarily on how mandated "relocation" of an item affects opportunistic

\footnotetext{
${ }^{6}$ Given the lack of a technical definition of operating income, ASU 2017-07 requires "an entity to present the other components of net benefit cost [other than service cost] outside a subtotal of income from operations, if one is presented... If a subtotal of income from operations is not presented, the entity will have discretion to present the other components of net benefit cost wherever it is appropriate in the income statement" (ASU 201707, Paragraph BC20).
} 
management of that item, and market perceptions thereof through outcomes such as value relevance, earnings response coefficients, and analyst forecast errors (Bartov and Mohanram 2014; Luo, Shao, and Zhang 2018; Kang, Lin, and Yeung 2019). In a point of departure from this work, we directly examine the "real" effects of GAAP-mandated relocation. Cohen, Katz, Mutlu, and Sadka 2019 also document the real effects of higher leverage in response to mandated relocation of minority interests from liabilities (or mezzanine) to shareholders' equity. Our study is in a similar spirit to theirs, with the key difference that our setting relocates components on the income statement, rather than the balance sheet.

Third, our findings have an interesting parallel to Anantharaman and Chuk's (2018) findings that pension risk-taking declined upon IFRS' adoption of IAS 19R, which removed the ERR assumption altogether from net income. ${ }^{7}$ The reporting changes implemented by each standard-setter fundamentally differ - the IASB removed the expected return component from net income altogether (a measurement change), whereas the FASB simply relocates it out of operating income (a presentation change). Nonetheless, both actions appear to engender reductions in any tilt that pension portfolios had towards risky investments. Collectively, they provide evidence from very different settings both pointing to the broader conclusion that financial reporting - specifically, income statement benefits - are a driver of pension asset allocation choices, a conjecture long held by pension experts (Zion and Carache 2002, 2005; Gold 2005).

The rest of our paper is organized as follows. Section II discusses the institutional background on the regulation and develops hypotheses. Section III describes our data and research design. Section IV reports empirical results. Section V summarizes and concludes.

\section{BACKGROUND AND HYPOTHESIS DEVELOPMENT}

\footnotetext{
${ }^{7}$ IAS 19 (Revised) Pension Benefits. Under IAS 19R, pension costs are now offset by an expected return calculated not based on an ERR, but rather based on the plan's discount rate, which in turn is based on highquality corporate bond yields. This change was motivated in part by increasing concerns over ERR inflation.
} 


\section{The extant pension expense model}

Starting from the issuance of SFAS 87 in $1985,{ }^{8}$ pension expense on sponsoring firms' income statements is composed of the core "operating" cost of pensions - the service cost (i.e., the cost of additional benefits earned by participants for one more year of service), and the interest cost (the cost of carrying the liability, arising from benefits' being discounted by one less year), offset by the returns earned by pension assets. Under the "smoothing" model of pension expense adopted by SFAS 87, service costs and interest costs are offset by expected (not actual) returns on pension assets, computed as the fair value of pension assets multiplied by an ERR assumption. ${ }^{9}$

\section{Real effects of the ERR-based pension expense model}

The ERR assumption is left to managers' discretion, with FASB guidance that it must be based on the expected returns of the asset portfolio. ${ }^{10}$ As higher-risk assets bring higher expected returns on average, shifting pension portfolios towards riskier assets can help to justify higher ERR assumptions, which in turn reduce pension expense and boost reported net income. At the same time, the cost of investing in those riskier assets - namely, higher volatility in actual returns - is not borne on the income statement. In a nutshell, the ERR-based accounting model does not symmetrically reflect the expected costs and benefits of risk-taking-

\footnotetext{
${ }^{8}$ Statement of Financial Accounting Standards (SFAS) No: 87: Employers' Accounting for Pensions (FASB 1985).

${ }^{9}$ The difference between expected and actual returns is a part of "actuarial gains and losses" (hereafter, "AGLs"), which are recognized in other comprehensive income (OCI), in essence a dirty-surplus item. These AGLs, which include not only differences between actual and expected return but also differences between actuals and estimates of other actuarial assumptions (discount rates, mortality rates, salary growth rates, etc.), can move in offsetting directions and are all recognized in the aggregate in OCI. If this pool of accumulated AGLs exceeds a threshold, or "corridor" - currently 10 percent of the larger of the projected benefit obligation (PBO) and fair value of plan assets-it must then be amortized into net income (or "recycled") over the remaining average expected service life of beneficiaries. As a result, actual returns are recognized eventually in net income, but only through the recycling process, which usually occurs at a "glacial" pace, if at all (Picconi 2006), under U.S. GAAP.

10 SFAS 87, Paragraph 45: "The expected long-term rate of return on plan assets shall reflect the average rate of earnings expected on the funds invested or to be invested to provide for the benefits included in the projected benefit obligation. In estimating that rate, appropriate consideration should be given to the returns being earned by the plan assets in the fund and the rates of return expected to be available for reinvestment."
} 
it "highlights the rewards of equity but obscures the risks" (Frieman et al. 2005), and could hence tilt managers towards more risk-taking in pension portfolios than they would have undertaken otherwise.

Prior studies have documented evidence consistent with this purported effect, both within the ERR-based accounting regime and in settings involving changes out of that regime. Within the ERR-based regime in the U.S., Bergstresser, Desai, and Rauh (2006) and Chuk (2013) provide evidence that managers seeking the income boost from a higher ERR also take the real actions of increasing risky asset allocations in their pension plans; this leaves us with the inference that the pension portfolios of firms seeking an income boost are riskier than they would have been in the absence of ERR-based pension expensing. Anantharaman and Chuk (2018) provide the most direct evidence informing on the ERR-based accounting model itself, investigating the IFRS shift that removed the ERR altogether from net income. They predict, and find, that once the ERR assumption no longer affects reported net income under IAS 19R, the affected firms pull back on risky investments - suggesting that ERR-based accounting induced at least some portfolio tilt toward risk.

\section{Removal of pension cost components from operating income under ASU 2017-07, and its real effects}

With ASU 2017-07, the FASB has undertaken its first major change to pension accounting on the income statement since SFAS 87. The ASU alters the presentation of pension expense on the income statement, in two ways. First, it requires pension expense to be disaggregated into service cost and all non-service cost components. Second, it requires service cost to be reported in the same line item as other compensation costs arising from services rendered by employees during the period; typically, these will include salaries and bonuses, and would be reported as an operating cost. All non-service cost components of pension expense - this includes interest costs, the expected return on pension assets, amortization of actuarial gains/losses and prior service costs, and other items such as net gains/losses on 
curtailments and settlements - are to be reported separately and outside operating income, if operating income is reported separately on the income statement. Importantly, no new information is disclosed as a result of this disaggregation: all pension expense components were previously required to be individually disclosed on the pension footnote, per SFAS 87 . Appendix A details the reporting changes mandated by ASU 2017-07.

Under the ASU, the ERR assumption continues to affect net income, but no longer affects operating income. Prior to the ASU, raising the ERR would boost both operating income and net income; after the ASU, raising the ERR boosts only net income while keeping operating income unchanged.

As a result, ASU 2017-07 reduces the financial reporting benefits of inflating the expected return component, which (along with several other components) is relegated from "above the line" of operating income to "below the line". To the extent that firms were investing in risky pension assets to garner financial reporting benefits prior to ASU 2017-07 (i.e., of justifying a higher ERR and boosting the expected return component), those financial reporting benefits to investing in risky pension assets are reduced after ASU 2017-07. Thus, we predict some "unwinding" of those risky investments after ASU 2017-07's reduction of those financial reporting benefits. Our main prediction follows:

H1: $\quad$ Firms affected by ASU 2017-07 will reduce risk-taking in pension asset allocations following the adoption of ASU 2017-07.

Note that many other costs and benefits also drive pension asset allocation to riskier versus safer assets. For example, sponsors could invest in riskier assets (such as equities) as their greater expected returns allow benefits to be provided more cheaply in the long-run, or because equities provide a better hedge against real salary increases, or to maximize the value of the put option provided by Pension Benefit Guaranty Corporation insurance (Rauh, 2009; Sharpe, 1976). Sponsors could invest in safer assets (such as bonds) for tax arbitrage reasons (Black 1980, Tepper 1981, Frank 2002) or to better match pension assets with the bond-like 
nature of benefit obligations. The ASU does not alter any of these economic costs or benefits, but only potentially reduces the financial reporting benefits to investing in riskier assets.

Another way to think of the ASU's effects is by considering sponsors' trade-offs to investing in equities: investing in equities brings many benefits described above, but also entails costs, primarily that of greater volatility in funding and hence in cash contribution requirements into plans. Unpredictable cash flows required to be diverted into pension funding can play havoc with sponsors' ability to proceed with their investment agenda (e.g., Rauh 2006). ${ }^{11}$ Given these costs, any reduction in the financial reporting benefits to risk-taking could, at the margin, make those risky investments less attractive to sponsors.

\section{Does ASU 2017-07 reduce the financial reporting benefits of a higher ERR?}

Some fundamental questions on financial statement presentation and its consequences underpin our prediction, and act as sources of empirical tension. A key assumption underlying $\mathrm{H} 1$ is that the financial reporting benefits of a higher ERR have declined under the ASU, as a higher expected return no longer boosts operating income (even while continuing to boost net income).

Justifying this assumption is a stream of research on how investor perceptions are affected by the relative position of line items on the income statement. Generally, the closer an item is to the topline (sales revenues), the more permanent investors perceive it as, with correspondingly higher value-relevance (e.g., Lipe 1986, Bradshaw and Sloan 2002, Fairfield et al. 1996, Ohlson and Penman 1992). Conversely, the lower down an item is on the income statement - the very direction in which the pension expected return has now moved - the more transitory investors perceive it as, with correspondingly lower value-relevance. Moreover, managers respond to these distinctions by e.g., shifting expenses out of core earnings into

\footnotetext{
${ }^{11}$ CFOs have been known to describe DB plans as a "volatile debt" that they are forced to carry on their balance sheets (Shumsky, 2018), which "consistently defies planning and budgeting exercises" - see https://buck.com/losing-sleep-over-pension-financials-not-these-cfos-heres-why/.
} 
(lower down) special items, implying that they are aware of the differential valuation implications of varying line-item location. Bartov and Mohanram (2014) get closest to clean inference on these implications, in their study of SFAS 145, which moved gains/losses from early debt extinguishment out of extraordinary items, i.e., below-the-line of net income, to above-the-line of net income (before extraordinary items). They document that investors react more strongly to these gains/losses when they are reported above-the-line, broadly consistent with higher-level placement of an income statement item increasing its value-relevance, even though the economic content of the item may be unchanged.

Furthermore, analysts and investors have increasingly focused on performance measures other than GAAP net income - variously labeled "core" / "proforma" / "operating" income or "Street" earnings; managers have increasingly provided such measures voluntarily (e.g., Bradshaw and Sloan 2002). Even the FASB warns against "focusing attention almost exclusively on 'the bottom line"'. ${ }^{12}$ The objective of such proforma measures calculated by analysts and managers, presumably, is to approximate a "core" earnings that better reflects sustainable, ongoing performance. The fact that these measures typically exclude nonrecurring, presumably transitory items as well as other items considered "non-operating" suggests that operating income better approximates "core" earnings than does net income. The widespread prevalence and value-relevance of such measures implies, at the minimum, that investors find metrics of operating income (or variants thereof) decision-relevant.

More specific to our setting, operating income in itself has been shown to be a useful metric for investors' decision-making, notwithstanding the general focus on net income. Barton, Hansen, and Pownall (2010) compare many summary measures of performance for 46 countries including the U.S. - from sales revenues to operating income to net income to

\footnotetext{
${ }^{12}$ The FASB continues with "The individual items, subtotals, or other parts of a financial statement may often be more useful than the aggregate to those who make investment, credit, and similar decisions" (FASB Concept Statement No. 5, Paragraph 22)."
} 
comprehensive income - and document that value-relevance tends to peak as one moves towards the "middle" of the income statement (to operating income, and variants thereof).

Operating income could also matter from a contracting perspective - Ittner, Larcker, and Rajan (1997) document that it is one of the most commonly-used performance metrics in CEO annual bonus contracts, along with net income and EPS; Huang, Li, and Ng (2013) confirm this in a much larger and more recent sample. ${ }^{13}$

In sum, there are many reasons to believe that operating income is regarded as a useful metric by market participants and contracting parties; managers, in turn, focus on the metrics that are widely used. ${ }^{14}$ Hence, the desire to boost operating income - for valuation and/or contracting purposes - could have incentivized managers to increase risk in pension portfolios prior to the ASU. As those incentives no longer exist, some unwinding of pension risk could result.

Some key countervailing forces still remain. First, unlike IAS 19R - which removes the effect of the ERR entirely from the income statement, under ASU 2017-07 the ERR continues to have the ability to boost net income. Notwithstanding the growing use of nonGAAP earnings measures, the importance of net income in firm valuation remains indisputable, and it continues to be widely used in contracting. Therefore, it remains an open question whether the ASU's reduction of the financial reporting benefits of pension risk-taking are substantial enough to trigger unwinding of risky asset allocations, the expected-return effects of which can after all still flow into - and benefit - net income.

\footnotetext{
${ }^{13}$ Guay, Kepler, and Tsui (2016) also document that CEO bonus plans typically incorporate multiple performance measures, including 1-2 earnings-based measures on average, ranging from net income to operating income to higher-level subtotals and scaled return-type measures. They do not, however, provide statistics on the relative usage of each measure.

${ }^{14}$ A stream of research has documented evidence of earnings management in performance metrics that are widely used by stakeholders and - just as importantly - a lack of evidence of earnings management in performance metrics that are not widely used by stakeholders (Dechow, Richardson, and Tuna 2003; Jacob and Jorgensen 2007; Jorgensen, Lee, and Rock 2014; Burgstahler and Chuk 2015, 2017).
} 
Second, we note here that pension expense has been disaggregated component-bycomponent in the pension footnote since SFAS 87, and that even prior to ASU 2017-07, some sophisticated financial statement users were computing proforma measures of pension cost by re-arranging and/or re-measuring certain pension cost components (Standard \& Poor's 2003; Moody's 2006; Moody's 2016, ASU 2017-07 Paragraph BC12). Many of these users commented in the exposure process leading up to ASU 2017-07 that their proforma adjustments to pension expense (and in turn to operating income) were very similar to what the FASB proposed and eventually issued as authoritative guidance in ASU 2017-07. To the extent that managers believed, pre-ASU, that financial statement users were already removing expected returns from operating income, then they would have relatively low incentives to take real actions - such as increase pension risk - specifically in order to boost operating income. And in that scenario, we would not then expect the passage of the ASU - which simply mandates a rearrangement that mimics the numbers already used in practice - to significantly alter managerial behavior with respect to pension asset allocations.

Finally, pre-ASU 2017-07 accounting rules need not have incentivized all firms to increase risk-taking similarly. Prior to ASU 2017-07, inflating the expected return component was likely to have been more effective for some firms, relative to others, at boosting reported operating income. Hence, the risk-taking induced by the desire to boost operating income for these firms was also likely higher prior to ASU 2017-07. We expect that these firms experience a correspondingly greater "unwinding" of risky asset allocations post-ASU 2017-07. Accordingly, we exploit cross-sectional variation in how effectively the ERR could boost operating income to offer a further prediction:

H2: $\quad$ The reduction in risk-taking in pension assets after ASU 2017-07 will be more pronounced for firms for whom inflating the expected return component was more effective at increasing operating income prior to ASU 2017-07. 
Following a similar logic, the ASU's "unwinding" of the financial reporting benefits of risk-taking is likely to have been stronger for some firms than for others. To put it simply, if operating income really "mattered" to a firm pre-ASU (and managers perceived that correctly), then the ASU's relocation of expected return out of operating income likely reduced the financial reporting benefits of risk-taking more for that firm. Conversely, if operating income is not a salient metric (for valuation or contracting) - because instead, say, net income is the dominant measure of interest for that firm - then, the ASU may not have substantially reduced the financial reporting benefits of risk-taking for that firm. We would expect a correspondingly greater "unwinding" of risk-taking for the former, rather than the latter, firm. Our third hypothesis follows:

H3: $\quad$ The reduction in risk-taking in pension assets after ASU 2017-07 will be more pronounced for firms for whom the financial reporting benefits of risk-taking are reduced more by the ASU.

\section{DATA AND EMPIRICAL MODEL}

\section{Constructing a treatment sample of U.S. firms}

Table 1 outlines the sample selection process. We start by identifying all U.S. firms with DB pensions that are represented in Compustat North America for the last fiscal period before ASU 2017-07 and the first fiscal period under ASU 2017-07. As ASU 2017-07 became effective for fiscal years beginning after December 15, 2017, for December fiscal year-end firms this translates into fiscal years 2017 (pre-ASU) and 2018 (ASU) respectively. We obtain annual reports for these firms from the SEC website, giving us an initial sample of 1,328 firms.

We hand-collect the detailed pension asset allocations, ERRs, and discount rates from annual reports for the two-year time period extending from the last fiscal period before adoption of ASU 2017-07 to the first fiscal period post-adoption. We lose 498 firms due to missing data required for our model variables. We also lose 80 firms that do not have sufficient data in both the pre- and post-periods. Finally, we remove four firms that are voluntary early 
adopters of the provisions in the ASU, given that changes in managerial behavior (if any) for early adopters would likely have occurred prior to our time window. Our final sample of 746 U.S. firms translates to 1,492 firm-years for the U.S. "treatment" sample.

\section{Selecting a control sample of Canadian firms}

To make reliable inferences about the effects of ASU 2017-07 and to rule out macroeconomic or over-time influences, we choose a control sample of Canadian listed firms that sponsor DB pension plans. Canadian firms are geographically proximate to U.S. firms and share a similar capital markets environment, but are presumably unaffected by ASU 2017-07, as Canadian firms have reported under IFRS since around 2013. Importantly, the measurement and presentation of pension expense components under IFRS underwent no alterations during the time window we examine. Under IAS 19R, there is no specific mandate as to where pension cost components should be presented on the balance sheet or even whether the components must be presented separately; firms are allowed to choose a presentation approach under the expectation that it is consistently applied. For all these reasons, we believe that Canadian firms offer an appropriate control sample to evaluate the treatment effects of ASU 2017-07. We use entropy balancing when estimating the effects of ASU 2017-07.

We rely on Compustat North America for financial and pension data on Canadian firms; we find 198 Canadian firms that sponsor DB pensions. We lose 49 firms due to missing data for model variables and 10 firms that do not have sufficient data in both periods. Our final sample of 139 Canadian firms translates to 278 firm-years for the Canadian control sample.

We obtain annual reports for these firms from Canada's online repository of public company filings, SEDAR, supplemented by hand-collection from company websites. We hand-collect detailed pension asset allocations, ERRs, and discount rates from Canadian annual reports for the same two-year time period as for the treatment sample. We convert all numbers from CAD to USD using the exchange rate at the fiscal year-end. 


\section{Specification to test the consequences of ASU 2017-07}

We identify the overall effect of ASU 2017-07 with a difference-in-differences (DD) specification, which compares pre- and post-ASU 2017-07 shifts in asset allocation of U.S. firms affected by ASU 2017-07, to shifts over the same time in asset allocations of Canadian control firms. We employ the following OLS specification:

$\%$ EQUITIES (or $\%$ FIXED INCOME) $=\beta_{0}+\beta_{1}$ POST $+\beta_{2}$ US $+\beta_{3}$ POST $*$ US $+\Sigma$ Controls

$$
+ \text { FIRM FE }+\varepsilon(\text { Equation 1) }
$$

The dependent variable \%EQUITIES captures the proportion of pension assets invested in equity and equity-like securities, and is hand-collected from the detailed asset allocation disclosures on annual reports of U.S. and Canadian sponsors. We also estimate an alternative version of Eq. (1) with \%FIXED INCOME - the proportion of pension assets invested in relatively safe instruments, i.e., fixed-income securities. We hand-collect these allocations to better capture the richness and complexity of these disclosures, which are not fully reflected on Compustat Pensions (Anantharaman and Chuk 2020).

US is a firm-level indicator set to one (zero) for U.S. (Canadian) firms. POST is an indictor set to one for firm-years under ASU 2017-07, and to zero for firm-years ending before the ASU became effective. Our key variable of interest is the DD estimator on the interaction POST*US, which captures the incremental change in asset allocations of U.S. pension plans, relative to Canadian plans.

Our control variables capture cross-sectional determinants of asset allocations, motivated by prior research. We control for sponsor size (SIZE) as larger sponsors have wider investment opportunities. Firms with tighter debt covenants or with a tradition of paying dividends have stronger incentives to minimize volatility in pension returns (and consequently in funded status or required contributions), so as to avoid breaching covenants or to preserve the cash flows needed to pay dividends. Accordingly, we control for closeness to covenant 
thresholds with leverage (LEVERAGE), and for dividend-paying status (DIVIDENDS). Firms with volatile operating cash flows would also have an incentive to minimize volatility in pension returns (and consequently in required contributions), motivating cash flow volatility (SDCF) as a control variable. Black (1980) and Tepper (1981) argue that tax-paying firms have an incentive to borrow on the corporate balance sheet, fund their plans and invest plan assets in the most highly taxed securities - bonds. ${ }^{15}$ This "tax arbitrage" argument suggests that high tax-paying firms invest more in bonds. We incorporate an indicator variable set to one if the firm has net operating loss carryforwards (NOL), to capture the firm's tax-paying status.

Amongst plan-level characteristics, we control for funding ratio (FUND RATIO) and the square thereof (FUND RATIO ${ }^{2}$ ), as prior research hypothesizes that very overfunded and very underfunded plans - in an attempt to minimize contribution volatility - tend to invest in bonds, while moderately funded plans increase equity investments to earn their way out of underfunding (Bader 1991, Amir and Benartzi 1999). We control for plan horizon (HORIZON, measured as the natural logarithm of $\mathrm{PBO} /$ service cost), as longer-horizon plans (with younger beneficiaries) should invest more in equities to hedge against salary increases (Rauh 2009). Finally, not all sponsors rebalance allocations to target period-by-period; hence, equity investments can grow as a proportion of total plan assets in years when equity markets perform well. To control for passive growth in equity investments, we include the broad-based performance of global equity markets, with returns to the S\&P Global Broad Market Index for equities (MARKET RETURNS). ${ }^{16}$ We also control for firm fixed-effects. We cluster standard errors at the firm level. Appendix B provides detailed variable definitions.

\section{EMPIRICAL RESULTS}

\footnotetext{
15 This strategy helps to maximize shareholder value as sponsors can then deduct interest off the corporate tax return but accrue interest tax-free on the bonds held inside the pension trust.

16 As a result of less-than-perfect rebalancing, in a year in which the equity markets perform well, equity allocations can grow for all sponsors (and vice-versa if the equity markets do not perform well). As our DD specification involves comparisons across time, overall equity market performance in each time period hence becomes an important factor that needs to be controlled for.
} 


\section{Descriptive statistics of model variables for the U.S. sample (treatment group)}

Table 2 describes model variables, with Panel A (Panel B) describing the U.S. sample pre- (post-) ASU 2017-07. Equities are the largest category on average for U.S. plans pre-ASU 2017-07, with mean (median) investment of 40.4\% (43.2\%) of pension assets. We observe a marked downward shift in \%EQUITIES after ASU 2017-07, to a mean (median) of 34.8\% $(36 \%)$. Notably, the entire distribution of \%EQUITIES appears to shift downwards - the $25^{\text {th }}$ percentile declines from $25.3 \%$ to $16.8 \%$, and the $75^{\text {th }}$ percentile declines from $57.6 \%$ to $52 \%$.

Fixed income securities, the second largest category for U.S. plans, display a corresponding upswing along the entire distribution - the mean (median) investment in fixed income securities (\%FIXED INCOME) increases from 40.6\% (38.6\%) to 45.3\% (42.9\%), with the $25^{\text {th }}$ percentile increasing from $27.7 \%$ to $31.4 \%$, and the $75^{\text {th }}$ percentile increasing from $51.7 \%$ to $58.3 \%$. Unsurprisingly, ERRs also decline from $6.2 \%$ (6.50\%) to 5.97\% (6.25\%).

The market value of firm equity starts out at $\$ 14.9 \mathrm{bn}(\$ 3.5 \mathrm{bn})$ in the pre-period, dropping marginally to about $\$ 13.8 \mathrm{bn}(\$ 2.9 \mathrm{bn})$ in the post-period. Similarly, the fair value of plan assets, which is $\$ 1.7 \mathrm{bn}(\$ 297.8 \mathrm{~m})$ in the pre-period, drops slightly to $\$ 1.6 \mathrm{bn}(\$ 272.6 \mathrm{~m})$ in the post-period. Funding ratios, however, remain steady at $83.6 \%(84.2 \%)$ in the pre-period and $83.2 \%(83.5 \%)$ in the post-period. Other fundamentals such as leverage, dividends, cash flow volatility, loss carryforwards, and plan horizon do not exhibit noteworthy trends across periods. Market returns are on average positive in the pre-period, and on average negative in the post-period.

\section{Descriptive statistics of model variables for the Canadian sample (control group)}

Panel A (Panel B) of Table 3 describes the Canadian sample pre- (post-) ASU 2017-07. \%EQUITIES has an interquartile range of $31 \%-59 \%$ in the pre-period (broadly similar to the U.S. sample), with a mean (median) of $43 \%$ (46\%), slightly higher than the U.S. sample. The 
mean (median) of \%EQUITIES drops to $39.1 \%$ (41\%) post-ASU; \%FIXED INCOME starts out at $40.7 \%(39 \%)$ - very similar to the U.S. sample, and increases to $43.2 \%(42 \%)$.

Figure 1 graphically represents the mean and median values of \%EQUITY for the U.S. and Canadian samples in the pre- and post-periods. We note that both samples experience a reduction in equity holdings, likely due to the poor performance of global equity markets in 2018. However, importantly, the change in \%EQUITIES appears more negative for U.S. firms. Overall, the broadly similar shifts in asset allocations across U.S. and Canada highlight the importance of our DD research design, where potential common macro-economic trends are differenced away. We discuss this specification next.

\section{Difference-in-differences tests of the effect of ASU 2017-07}

In Table 4, we present results of estimating the DD specification of Equation (1) with U.S. and Canadian firms, pre- and post-ASU 2017-07. To more confidently infer treatment effects of the ASU, we implement multivariate matching across U.S. and Canadian samples using an entropy balancing approach. Like other multivariate matching approaches (e.g., propensity score matching, which is commonly used in accounting and finance studies), the goal of entropy balancing is to eliminate differences in covariates across treatment and control samples. Entropy balancing, however, has two key conceptual advantages over propensity score matching (McMullin and Schonberger 2020): it ensures that higher-order moments of covariate distributions are nearly identical across treatment and control samples; and it does away with the many researcher choices that are necessary for propensity score matching and which can greatly influence the results thereof. McMullin and Schonberger (2020) highlight that entropy balancing has particular strengths in settings where the outcome variable is a nonlinear function of the underlying controls - a feature applicable to our setting, where asset allocation has long been understood to be non-linearly affected by plan funding (Bader 1991, Amir and Benartzi 1999, Anantharaman and Lee 2013). Entropy balancing also offers the 
empirical advantage of allowing us to retain our full U.S. and Canadian samples. We provide details of the entropy balancing procedure in Appendix C, with the pre- and post-balancing distributional properties of U.S. and Canadian samples summarized in Table C1. Table C1 shows very similar means for matching variables after entropy balancing.

We present results of Eq. (1) without entropy balancing in Table 4, Panel A, and using entropy balancing in Panel B. Columns (1) and (3) [(2) and (4)] display specifications with \%EQUITIES [\%FIXED INCOME] as the dependent variable. The POST indicator is strongly significant across Columns (1)-(4), indicating a drop in equity investment to the tune of $3.07 \%$ $3.19 \%$ post-ASU for all firms, and an accompanying increase in fixed income investment to the tune of $3.23 \%-3.36 \%$. Importantly, our main coefficient of interest, US*POST, is negative and significant at the $<0.05$ level in specifications with \%EQUITIES, while positive and significant at the $<0.01$ level in specifications with \%FIXED INCOME. The coefficients on US*POST indicate that after controlling for various determinants of asset allocation, U.S. firms reduce equity allocations post-ASU by $1.58 \%-2.20 \%$ more than Canadian firms, and increase fixed-income allocations by $2.16 \%-2.60 \%$ more than Canadian firms, on average. As U.S. firms are affected by ASU 2017-07 whereas Canadian firms are presumably unaffected, this provides direct evidence consistent with H1 that ASU 2017-07 engenders risk reduction.

\section{Cross-sectional variation in the financial reporting benefits of risk-taking}

The DD research design helps to a large extent in ruling out omitted variables concerns arising from permanent, time-invariant differences across U.S. and Canada, or global macroeconomic trends or market movements affecting both countries. In order for our results to be explained by an omitted variable, the omitted variable would have to time-vary contemporaneously with ASU 2017-07 implementation, and affect U.S. and Canadian plans differently. Nevertheless, to further verify that U.S. risk-reduction is attributable to ASU 201707, we examine cross-sectional partitions varying the expected strength of the ASU's effect. In 
our first set of partitions, we examine subsamples in which we expect the financial reporting benefits of risk-taking to have been most pronounced in the first place, pre-ASU 2017-07. If the risk-reduction observed in U.S. plans is truly attributable to our hypothesized mechanism, then we would expect the risk-reduction to be stronger for these firms, whose asset allocations were presumably more influenced by reporting incentives to begin with $(\mathrm{H} 2)$.

To test H2, we operationalize the strength of the pre-ASU 2017-07 incentives to invest in risky assets in order to boost the expected return, using two different proxies. Our first measure is the ratio of the expected return component to all other components of pension costs (results presented in Table 5). This captures sponsors for which the expected return is an economically significant component of pension expense, and is hence more likely to offset the other (income-decreasing) pension cost components. Our second measure is the ratio of fair value of pension assets to operating income (results presented in Table 6); it captures how powerful the ERR is, as a lever to boost operating income (Bergstresser, Desai, and Rauh 2006). As the expected return component is calculated as ERR*fair value of ending pension assets, any given increase in the ERR has a greater impact on operating income for a firm with large pension assets; the ratio of fair value of plan assets / operating income hence captures the extent of this multiplier effect. Sponsor with greater multipliers, we assume, have greater incentives pre-ASU to boost the ERR.

In each of Tables 5 and 6 , we partition the sample by median values of each of the three measures, resulting in a subsample with high incentives and a subsample with low incentives. We separately estimate Equation (1) for each of two resulting subsamples, with Panel A in each table reporting the results of estimating Equation (1) for the subsample with high incentives, and Panel B reporting results for the subsample with low incentives. Our subsamples display economically significant differences along the partitioning variables: median expected returns 
are $94.5 \%$ (54\%) of other pension costs for the high (low) subsample; and median plan assets to operating income is 2.3 (0.4) for the high (low) subsample.

Tables 5 and 6 collectively paint a picture of the reduction in risk-taking being concentrated in firms with greater financial reporting benefits to hold risky pension assets prior to ASU 2017-07, consistent with H2. In Tables 5 and 6, the coefficient of interest US*POST is significant at the $<0.01$ level throughout in Panel A for the high incentive subsamples, whereas it is not significantly different from zero in Panel B, for the low incentive subsamples. The coefficients indicate an incremental reduction in U.S. firms' equities to the tune of $3.52 \%$, and $2.37 \%$ in the high-incentive subsamples in Tables 5 and 6 respectively. This translates into $16.7 \%$ and $11.8 \%$ respectively of one standard deviation in U.S. \%EQUITIES from the preASU period - indicating economically significant shifts in asset allocation.

Collectively, these results present a picture of stronger reductions in equity investment for the subsamples of firms that were more subject to the reporting-based risk-taking incentives to begin with. As these types of firms likely had larger risky positions to "unwind" after ASU 2017-07, these cross-sectional patterns help us to isolate the ASU's reduction of reported-based incentives as being a driving factor behind the results we observe.

\section{Cross-sectional variation in the ASU's unwinding of the financial reporting benefits of risk-taking}

In our second set of cross-sectional partitions, we hone in specifically on the strength of the ASU's purported effect, of reducing the financial reporting benefits of risk-taking. If the reduction in risk-taking is specifically attributable to the ASU's shift of expected return out of operating income and solely into net income, we would expect a larger effect for firms for which operating income was particularly important as a summary metric of performance - and for which the financial reporting benefits of a higher expected return (in that operating income) have hence declined more significantly. 
We operationalize the importance of operating income as a summary metric with two proxies. First, we isolate firms for which at least one analyst (on the I/B/E/S database) issues an explicit forecast of operating income. Analyst focus on operating income is interesting for multiple reasons - it could indicate firms for which the operating income is an intrinsically more useful summary performance measure, relative to net income (for reasons associated with firm fundamentals, industry fundamentals, or firm reporting behavior). ${ }^{17}$ Furthermore, analysts' focus on operating income could in turn engender greater attention to that metric from other investors and market participants. Second, we directly examine the decision-usefulness of operating income, relative to net income, for equity investors' valuation. To gauge this, we estimate firm-specific regressions of price on operating income, and of price on net income, and partition firms by the ratio of the $\mathrm{R}^{2} \mathrm{~s}$ from these two models, which serves as our measure of the relative value-relevance of operating income versus net income.

We present these results in Table 7 (analysts' forecasts of operating income) and Table 8 (value-relevance of operating income relative to net income). In Table 7, about $45 \%$ of our sample firm-years have at least one analyst forecast of operating income. In untabulated estimations for Table 8 , we find that the $\mathrm{R}^{2}$ s from models of price on operating income are consistently higher than from models of price on net income - the mean $\mathrm{R}^{2}$ from operating income (net income) models is $23.2 \%$ (14\%) while the median $\mathrm{R}^{2}$ is $15 \%(7.86 \%)$, with very similar statistics across U.S. and Canadian samples. The median $\mathrm{R}^{2}$ of operating income relative to net income is 5.3 for the high subsample, versus 0.6 for the low subsample.

The subsample results in Tables 7 and 8 are broadly consistent with our expectations: in both cases, the US*POST interaction is significant at the $<0.05$ level for the predicted subsample (with analysts' forecasts for operating income, and higher value-relevance of,

\footnotetext{
${ }^{17}$ Prior research on analyst forecasting decisions suggests that analysts respond to market participants' demand for value-relevant information when choosing to provide forecasts of additional summary metrics of firm performance (e.g., Brown and Sivakumar 2003, DeFond and Hung 2003).
} 
operating income). The difference in coefficients on the interaction across subsamples is not statistically significant for Table 7 , but is significant for Table 8 . The coefficients indicate an incremental reduction in U.S. firms' equities to the tune of $2.51 \%$ among firms with analysts' operating income forecasts, and $2.61 \%$ among firms with high value-relevance of operating income. These effects translate to $13 \%$ and $12.1 \%$ respectively of one standard deviation of U.S. equities.

Collectively, these cross-sectional results provide further evidence that helps us to attribute the risk-reduction specifically to ASU 2017-07's removal of expected return benefits from operating income.

\section{CONCLUSION}

Following an accounting rule change (ASU 2017-07) in the U.S. that mandates the relocation of the expected return on pension assets out of operating income, we document a reduction in affected U.S. firms' investment in riskier pension assets, relative to a control sample of Canadian firms that report under IFRS and are hence unaffected by the mandate. We infer from this that the pre-ASU financial statement presentation - wherein expected returns flowed into operating income - incentivized pension sponsors to invest in riskier assets. This inference is supported by cross-sectional tests demonstrating that the reduction in risk-taking is concentrated in sponsors (1) for which the financial reporting incentives for risk-taking, preASU, were stronger to begin with, and (2) for which the ASU particularly reduced those financial reporting benefits. Building on prior work (Bergstresser, Desai, and Rauh 2006; Chuk 2013; Anantharaman and Chuk 2018), these findings point to the expected returns-based accounting and financial reporting model as a key driver of pension risk-taking.

The particular setting we examine - ASU 2017-07 - also allows the opportunity to gain insights into which performance metrics "matter", and specifically, does operating income matter incrementally to net income? Mechanically, operating income is a subtotal of net 
income, such that any earnings component that is a part of operating income is, by construction, also included in net income. Thus, it is generally not possible to determine whether managerial actions undertaken to report a favorable number for such an earnings component are driven by incentives to report favorable operating income specifically, as opposed to incentives to report favorable net income. Our setting moves us closer to such inference. While net income - the bottom line on the income statement - is indisputably relevant for valuation and contracting, our findings imply that at least some of the pension risk-taking observed in the pre-ASU era were in the interest of reporting higher operating income. If stakeholders use operating income as a measure of core earnings, which reflects sustainable performance going forward, then managers could be responding to those perceptions by focusing in turn on operating income.

Perhaps the most surprising aspect of our findings is that U.S. GAAP, to date, has not formally defined operating income or formulated any rules for how operating income should be measured. Nor does U.S. GAAP require the disclosure of operating income in a multi-step income statement. Given the lack of guidance from the FASB for a metric to measure income from sustainable performance going forward, several non-GAAP measures — such as EBIT and EBITDA - have been contenders to fill that void in recent years. However, despite the rising popularity of non-GAAP earnings metrics, our findings demonstrate that operating income as reported on the income statement - still matters to managers. Or at the very least, managers believe that operating income matters to financial statement users. 


\section{References}

Amir, E., Benartzi, S. 1999. Accounting recognition and the determinants of pension plan asset allocation. Journal of Accounting, Auditing and Finance 14 (3): 321-343.

Anantharaman, D., Chuk, E. 2018. The economic consequences of accounting standards: Evidence from risk-taking in pension plans. The Accounting Review 93 (4): 23-51.

Anantharaman, D., Chuk, E. 2020. So similar, yet so different: Comparing the US GAAP and IFRS experience at eliciting greater transparency on pension asset disclosures. Working paper.

Anantharaman, D., Lee, Y.G. 2014. "Managerial risk-taking incentives and corporate pension policy." Journal of Financial Economics 111(2):328-351.

Bader, L. 1991. The Financial Executive's Guide to Pension Plans. New York, NY: Salomon Brothers, Inc.

Barton, J., Hansen, T.B., Pownall, G. 2010. Which performance measures do investors around the world value the most - and why? The Accounting Review 85 (3): 753-789.

Bartov, E., Mohanram, P. S. 2014. Does income statement placement matter to investors? The case of gains/losses from early debt extinguishment. The Accounting Review, 89(6), 2021-2055.

Bergstresser, D., Desai, M.A., Rauh, J.D. 2006. Earnings manipulation, pension assumptions and managerial investment decisions. Quarterly Journal of Economics 121: 157-195.

Black, F. 1980. The tax consequences of long-run pension policy. Financial Analysts Journal 36 (4): 21-28.

Bradshaw, M., Sloan, R. 2002. GAAP versus the street: An empirical assessment of two alternative definitions of earnings. Journal of Accounting Research 40: 41-66.

Brown, L.D., Sivakumar, K. 2003. Comparing the value relevance of two operating income measures. Review of Accounting Studies 8: 561-572.

Burgstahler, D., Chuk, E. 2015. Do scaling and selection explain earnings discontinuities? Journal of Accounting and Economics 60 (1): 168-86.

Burgstahler, D., Chuk, E. 2017. What have we learned about earnings management? Integrating discontinuity evidence. Contemporary Accounting Research 34 (2): 726-749.

Choudhary, P., Rajgopal, S., Venkatachalam, M. 2008. Accelerated vesting of stock options in anticipation of SFAS 123R. Journal of Accounting Research 47(1): 105-146.

Chuk, E. 2013. Economic consequences of mandated accounting disclosures: Evidence from pension accounting standards. The Accounting Review 88(2): 395-427.

Cohen, M., Katz, S., Mutlu, S., Sadka, G. 2019. Do debt covenants constrain borrowings prior to violation? Evidence from SFAS 160. The Accounting Review 94(2): 133-156.

Curtis, A. B., McVay, S.E., Whipple, B.E. 2014. The disclosure of non-GAAP earnings information in the presence of transitory gains. The Accounting Review 89(3): 933-958.

Dechow, P., Richardson S., Tuna, I., 2003. Why are earnings kinky? An examination of the earnings management explanation. Review of Accounting Studies 8, 355-384. 
DeFond, M.L., Hung, M. 2003. An empirical analysis of analysts' cash flow forecasts. Journal of Accounting and Economics 35(1): 73-100.

Fairfield, P., Sweeney, R., Yohn, T., 1996. Accounting classification and the predictive content of earnings. The Accounting Review, 71 (3), 337-355.

Ferri, F., Zheng, R., Zou, Y. (2018). Uncertainty about managers' reporting objectives and investors' response to earnings reports: Evidence from the 2006 executive compensation disclosures. Journal of Accounting and Economics, 66(2), 339-365.

Financial Accounting Standards Board (FASB). 1984. Statement of Financial Accounting Concepts No. 5: Recognition and Measurement in Financial Statements of Business Enterprises

Financial Accounting Standards Board (FASB). 1985. Statement of Financial Accounting Standards No 87: Employers' Accounting for Pensions. FASB: Norwalk, CT.

Financial Accounting Standards Board (FASB). 2001. Reporting Information about the Financial Performance of Business Enterprises: Focusing on the Form and Content of Financial Statements. Proposal for a New Agenda Project. Norwalk, CT.

Financial Accounting Standards Board (FASB). 2017. Accounting Standards Update No. 2017-07. Improving the Presentation of Net Periodic Pension Cost and Net Periodic Postretirement Benefit Cost. FASB: Norwalk, CT.

Frank, M.M. 2002. The impact of taxes on corporate defined benefit plan asset allocation. Journal of Accounting Research 40(4): 1163-1190.

Frieman, A., Pettit, J., Badakhsh, A., Barker, K. 2005. Optimal Capital Structure and the Corporate Pension. UBS Investment Banking Note. New York: UBS AG.

Gold, J. 2005. Accounting/actuarial bias enables equity investment by defined benefit pension plans. North American Actuarial Journal 9(3): 1-21.

Gordon, E.A., Henry, E., Jorgensen, B.N., Linthicum, C.L. 2017. Flexibility in cash-flow classification under IFRS: determinants and consequences. Review of Accounting Studies 22: 839872.

Guay, W.R., Kepler, J.D., Tsui, D. The role of executive cash bonuses providing individual and team incentives. Journal of Financial Economics 133(2): 441-471.

Hainmueller, J. 2012. Entropy Balancing for Causal Effects: A Multivariate Reweighting Method to Produce Balanced Samples in Observational Studies. Political Analysis, 20(1), 25-46.

Horwitz, B., Kolodny, R. 1980. The economic effects of involuntary uniformity in the financial reporting of research and development expenditures. Journal of Accounting Research 18: 38-74.

Huang, N., Li, N, Ng, J. 2013. Performance measures in CEO annual bonus contracts. Working paper, University of Texas at Austin, University of Texas at Dallas, and Chinese University of Hong Kong.

Ittner, C.D., Larcker, D.F., Rajan, M.V. 1997. The choice of performance measures in annual bonus contracts. The Accounting Review 72(2): 231-255.

Jacob, J., Jorgensen, B., 2007. Earnings management and accounting income aggregation. Journal of Accounting and Economics 43, 369-390. 
Jorgensen, B., Lee, Y.G., Rock, S., 2013. The Shapes of Scaled Earnings Histograms are Not Due to Scaling and Sample Selection: Evidence from Distributions of Reported Earnings Per Share. Contemporary Accounting Research.

Kang, C., Lin, S., Yeung, E. P. 2019. Where is the line? The effect of narrowed scope of discontinued operations on analysts' forecasts. Working paper, Cornell University and University of Memphis.

Laurion, H. 2020. Implications of Non-GAAP earnings for real activities and accounting choices. Journal of Accounting and Economics, 70(1), 101333.

Lee, Y., Petroni, K., Shen, M. (2006). Cherry picking, disclosure quality, and comprehensive income reporting choices: The case of property-liability insurers. Contemporary Accounting Research, 23(3), 655-692.

Lipe, R. 1986. The information contained in the components of earnings. Journal of Accounting Research 24: 37-64.

Luo, M., Shao, S., Zhang, F. 2017. Does financial reporting above or below operating income matter to investors? The case of investment income in China. Review of Accounting Studies 23: 1754-1790.

McVay, S. 2006. Earnings management using classification shifting: An examination of core earnings and special items. The Accounting Review, 81(3): 501-532

McMullin, J. L., \& Schonberger, B. 2020. Entropy-balanced accruals. Review of Accounting Studies, 1-36.

Moody's. 2006. Moody's Approach to Global Standard Adjustments in the Analysis of Financial Statements for Non-Financial Corporations-Part I. Available at: https://caremendoza.nd.edu/assets/152332/analytical_adjustments_part_i_updated.pdf

Moody's. 2016. Financial Statement Adjustments in the Analysis of Non-Financial Corporations. Available at: https://itfa.org/wp-content/uploads/2017/01/Global-StandardAdjustments-December-2016-1.pdf

Ohlson, J., Penman, S. 1992. Disaggregated accounting data as explanatory variables for returns. Journal of Accounting, Auditing and Finance 7: 553-573.

Picconi, M. 2006. The perils of pensions: Does pension accounting lead investors and analysts astray? The Accounting Review 81 (4): 925-955.

Rauh, J. D. 2006. Investment and financing constraints: Evidence from the funding of corporate pension plans. The Journal of Finance: 61(1): 33-71.

Rauh, J. D. 2009. Risk shifting versus risk management: Investment policy in corporate pension plans. Review of Financial Studies 22 (7): 2687-2733.

Sharpe, W. 1976. Corporate pension funding policy. Journal of Financial Economics 3: 183-193.

Shroff, N., Verdi, R. S., Yost, B. P. (2017). When does the peer information environment matter? Journal of Accounting and Economics, 64(2), 183-214.

Shumsky, T. October 15, 2018. Companies with newly flush pensions see chance to unload the risk. Wall Street Journal. 
Standard \& Poor's. 2003. Comment letter to FASB. File reference 1025-200, comment letter no. 4.

Tepper, I. 1981. Taxation and corporate pension policy. Journal of Finance 36 (1): 1-13.

Zhang, H., 2009. Effect of derivative accounting rules on corporate risk-management behavior. Journal of Accounting and Economics 47: 244-264.

Zion, D., and B. Carache. 2002. The Magic of Pension Accounting, Part I. Boston, MA: Credit Suisse First Boston.

Zion, D., and B. Carache. 2005. The Magic of Pension Accounting, Part III. Boston, MA: Credit Suisse First Boston. 


\section{Appendix A \\ Description of Reporting Changes Mandated by ASU 2017-07}

ASU 2017-07 under US GAAP became effective for fiscal periods beginning after December 15, 2017. Its main provisions require employers to report: (1) the service cost component of periodic pension cost in the same line item or items as other compensation costs arising from services rendered by the pertinent employees during the period, as part of operating income and (2) the other components of pension cost (besides service cost) separately from the service cost component and outside a subtotal of income from operations, if such a subtotal is presented. The FASB acknowledges that an entity may use a variety of presentations and subtotals on the face of the income statement, and therefore operating income is not always presented as a subtotal on the income statement. If operating income is not presented on the income statement, ASU 2017-07 allows the entity to have discretion to present the other components of pension cost other than service cost wherever it is appropriate in the income statement (ASU 2017-07, Paragraph BC20).

The FASB's reasoning for requiring the separation of service cost from the other components is that service cost is the component that exclusively originates from employee services during the current period, and potentially has a significantly different effect in terms of information usefulness to financial statement users. Below is a summary of the change in reporting requirements under ASU 2017-07 for each of the major components of pension cost, along with the resulting effects of whether the change increases or decreases reported operating income:

\begin{tabular}{|l|c|l|l|}
\hline & $\begin{array}{l}\text { Pre-ASU 2017-07: } \\
\text { Included in } \\
\text { operating income? }\end{array}$ & $\begin{array}{l}\text { Post-ASU 2017-07: } \\
\text { Included in } \\
\text { operating income? }\end{array}$ & $\begin{array}{l}\text { Direction of effect of } \\
\text { ASU 2017-07 on } \\
\text { operating income }\end{array}$ \\
\hline Service cost & Yes & Yes & No change \\
\hline Interest cost & Yes & No & Increase \\
\hline Expected return & Yes & No & $\begin{array}{l}\text { Increase for losses } \\
\text { Decrease for gains }\end{array}$ \\
\hline $\begin{array}{l}\text { Amortization of } \\
\text { gains/losses }\end{array}$ & Yes & No & Increase \\
\hline $\begin{array}{l}\text { Amortization of } \\
\text { prior service cost }\end{array}$ & Yes & & \\
\hline
\end{tabular}




\section{Appendix B \\ Variable Definitions}

\begin{tabular}{|c|c|c|}
\hline Variable & Description & Source \\
\hline \multicolumn{3}{|l|}{ Dependent Variables } \\
\hline$\%$ Fixed Income & Percentage of pension assets invested in fixed income securities & $10-K$ \\
\hline$\%$ Equities & Percentage of pension assets invested in equity securities & $10-K$ \\
\hline ERR & Expected rate of return & $10-k$ \\
\hline \multicolumn{3}{|c|}{ Independent Variables - Pension Characteristics } \\
\hline Post & $\begin{array}{l}\text { This indicator variable is set to } 1 \text { for fiscal years ending on or after Dec } 15^{\text {th }} \text {, } \\
2018 \text { and set to } 0 \text { for fiscal years ending Dec } 15^{\text {th }}, 2017 \text { to Dec } 14^{\text {th }} 2018 \text {. }\end{array}$ & \\
\hline US & This indicator variable is set to 1 for US firms, and 0 for Canadian firms & \\
\hline Horizon & $\begin{array}{l}\text { Investment horizon, measured as the natural } \log \text { of the ratio of PBO to current } \\
\text { service cost. If current service cost is } 0 \text { or blank, we replace the service cost by } \\
\text { a small value of } 0.000001\end{array}$ & pbpro, pbpru, svc \\
\hline Actual Returns (\$Million) & Current-year actual dollar return on pension assets & pbarat \\
\hline ARR 3yr avg & $\begin{array}{l}\text { Three-year average of ARR ending in the current year; where ARR is the } \\
\text { current-year actual dollar return on pension assets scaled by beginning pension } \\
\text { assets }\end{array}$ & pbarat, pplao, pplau \\
\hline Discount rate interest cost (\%) & Discount rate used to compute pension expense & ppcr, ppcrmax \\
\hline FVPA (\$ Million) & Fair value of plan assets at the end of the period & $10-k$ \\
\hline PBO (\$ Million) & Projected benefit obligation at the end of the period & $10-k$ \\
\hline Fund Ratio & $\begin{array}{l}\text { Funding ratio obtained from } 10-\mathrm{k} \text { data, measured as the fair value of plan } \\
\text { assets divided by the projected benefit obligation }\end{array}$ & 10-K, fvpa_ending, pbo_ending \\
\hline
\end{tabular}




\section{Independent Variables - Firm Characteristics}

SDCF (\$Million)

\section{Market Returns}

Market Cap (\$Million)

Size

Leverage (\$Million)

\section{NOL (\$ Million)}

\section{Dividends}

\section{Partitioning Variables}

High expected return/other pension costs

High fvpa/operating income

Analyst estimate available for operating profit
Operating risk, measured as the standard deviation of the ratio of cash flow from operations to book value of equity for five years, ending in the current year

12-month returns to S\&P Global Broad Market Index for equities

Market capitalization. It is the product of year-end share price and number of ordinary shares outstanding

Natural log of market cap

Ratio of long-term debt to total assets

It takes the value of 1 if prior period has a tax loss carry forward. Else, NOL takes the value of zero

Total dividends divided by total assets

This indicator variable is set equal to one when the ratio of expected return to all other components of pension cost is greater than the median, and set equa to zero otherwise.

The ratio of expected return to all other components of pension cost is computed as $(-1) *$ Dollar value of expected return divided by the value of all components of pension cost.

This indicator variable is set equal to one when the ratio of fair value of plan assets to operating income is greater than the median, and set equal to zero otherwise. If operating income is negative, we take the average of previous 3 years' operating income. If the 3 -year average is also negative, this variable is missing.

This indicator variable is set to one if there is at least one analyst estimate of operating profit, and set to zero otherwise oancf, bkvlps, csho

https://www.spglobal.com/spdji/en/indices/equity/spglobal-bmi/\#overview

\section{prcc_f, csho \\ prcc_f, csho \\ dltt, at}

\section{tlcf}

$d v c$, at

Expected return in $\$=$ pprpa

Other remaining pension costs $=$

(ppic + ppsc + ppopcc)

\section{Operating income $=O I A D P$}

FVPA is from 10-k 
This indicator variable is set to one when the ratio of R-square of operating

income regression to net income regression is greater than the median, and set

equal to zero otherwise. We define the median values of this ratio separately

for Canadian and US firms.

Both the operating income and net income regressions are run using 16

quarters of data just prior to the beginning of the post-period.

High value relevance of operating income
Operating Income regression:

$$
P_{i, t+3}=\alpha_{1}+\beta_{1} * \text { Operating } \text { Income }_{i, t}+\epsilon_{1}
$$

Net Income regression:

$$
P_{i, t+3}=\alpha_{2}+\beta_{2} * \text { Net } \text { Income }_{i, t}+\epsilon_{2}
$$

$P_{i, t+3}$ is the market value per share defined as the closing share price three months after the fiscal quarter end; Operating income and net income are per 


\section{Appendix C \\ Entropy balancing procedure}

We use entropy balancing method to achieve a balance of covariates between our treated sample (i.e., US firms) and control sample (i.e., Canadian firms). Entropy balancing creates a set of weights for the control sample such that the first, second, and higher moments of the covariate distributions in the treatment and the reweighted control sample are equalized (Hainmueller 2012). To achieve this, entropy balancing places higher weights on Canadian firms that are similar to the US firms along the chosen balancing dimensions (Ferri et al. 2018; McMullin \& Schonberger 2020; Shroff et al. 2017). Entropy balancing is particularly helpful in preserving the size of the control sample, which is pertinent when the size of the treated and control samples are vastly different (Laurion 2020).

We choose to balance on the mean of the following variables: size, leverage, $S D C F$, NOL, Dividend, PBO_handcollect, FVPA_handcollect, fundratio_compustat, fundratio_square_compustat, horizon. After entropy balancing, all the control variables above have equivalent means between the treatment and reweighted control sample.

One drawback of entropy balancing is that it could assign large weights to a handful of control observations, especially when there is less overlap between the treated and control sample (McMullin \& Schonberger 2020). This becomes a problem particularly in sub-sample analysis, where the number of control firms is low. As a result, entropy balancing in subsamples does not give us as close a distribution of balancing variables as in the main analyses. A similar issue of not having close distribution in sub-groups has been noted in Shroff et al. (2017).

Below, we tabulate the distribution properties of the US (treatment) firms and the Canadian (control) firms before and after applying our entropy balancing procedure. 
Table C1

Pre- and post-weighting distributional properties of treatment and control firms

\begin{tabular}{|c|c|c|c|c|c|c|c|c|c|}
\hline \multirow[t]{2}{*}{ VARIABLES } & \multicolumn{3}{|c|}{ US Pre-Period } & \multicolumn{3}{|c|}{$\begin{array}{c}\text { Before Entropy Balancing } \\
\text { Canada Pre-Period }\end{array}$} & \multicolumn{3}{|c|}{$\begin{array}{c}\text { After Entropy Balancing } \\
\text { Canada Pre-Period }\end{array}$} \\
\hline & $\mathrm{N}$ & Mean & SD & $\mathrm{N}$ & Mean & SD & $\mathrm{N}$ & Mean & SD \\
\hline Size & 746 & 8.128 & 1.917 & 139 & 7.413 & 2.090 & 139 & 8.127 & 1.681 \\
\hline Leverage & 746 & 0.252 & 0.189 & 139 & 0.253 & 0.186 & 139 & 0.252 & 0.160 \\
\hline $\operatorname{SDCF}(\$ ' m)$ & 746 & 0.338 & 1.201 & 139 & 0.537 & 1.835 & 139 & 0.340 & 1.264 \\
\hline NOL & 746 & 0.575 & 0.495 & 139 & 0.590 & 0.494 & 139 & 0.575 & 0.495 \\
\hline Dividend & 746 & 0.0166 & 0.0233 & 139 & 0.0153 & 0.0173 & 139 & 0.0166 & 0.0187 \\
\hline $\mathrm{PBO}\left(\mathrm{S}^{\prime} \mathrm{m}\right)$ & 746 & 1980 & 4674 & 139 & 1617 & 3243 & 139 & 1982 & 3233 \\
\hline FVPA (\$'m) & 746 & 1745 & 4187 & 139 & 1538 & 3196 & 139 & 1748 & 2874 \\
\hline $\begin{array}{l}\text { Fund Ratio } \\
\text { Fund Ratio }\end{array}$ & 746 & 0.836 & 0.194 & 139 & 0.875 & 0.189 & 139 & 0.837 & 0.194 \\
\hline Square & 746 & 0.737 & 0.328 & 139 & 0.800 & 0.295 & 139 & 0.737 & 0.278 \\
\hline Horizon & 746 & 7.495 & 5.770 & 139 & 6.043 & 5.102 & 139 & 7.496 & 6.382 \\
\hline
\end{tabular}

This table presents the distributional properties (mean and standard deviation) for US (treatment) and Canadian (control) firms in the original sample and after the reweighting of the control sample using entropy balancing technique. We use entropy balancing method to achieve a balance of covariates between our treated sample and control sample. We choose to balance on the mean of the variables listed in this table, using its values in the preperiod. The weights thus obtained for the control sample are used for the full period. 
Table 1

Sample Selection

No of firms that sponsor a defined benefit pension plan with data for the last fiscal year before ASU2017-07

Less: Observations with missing values for dependent variables and controls

Less: Observations dropped due to not having both pre- and post

\# Observations

Less: Voluntary early adopters

Number of firms in the sample
US

Canada

\# Observations

1,328

(498)

(80)

(4)

746

1492
198

(49)

(10)

(90)

(4)

Number of firms X 2 (one-year before and after ASU 2017-07)

Total

\# Observations

1,526

885 
Table 2

PANEL A: USA Sample: Pre-Period

\section{Descriptive Statistics - USA Sample}

\begin{tabular}{|l|ccccc|}
\hline & P25 & P50 & P75 & Mean & SD \\
\hline \%Equities & 25.33 & 43.22 & 57.61 & 40.41 & 21.68 \\
\%Fixed Income & 27.73 & 38.63 & 51.65 & 40.45 & 20.47 \\
ERR (\%) & 5.580 & 6.500 & 7.070 & 6.198 & 1.352 \\
SDCF (S'm) & 0.0341 & 0.0648 & 0.133 & 0.338 & 1.201 \\
Market Cap (S'm) & 1,165 & 3,494 & 13,547 & 14,920 & 32,090 \\
Leverage & 0.0911 & 0.253 & 0.355 & 0.252 & 0.189 \\
Horizon & 3.918 & 4.652 & 7.082 & 7.495 & 5.770 \\
Dividends & 0.00110 & 0.00960 & 0.0227 & 0.0166 & 0.0233 \\
Fund Ratio & 0.747 & 0.842 & 0.937 & 0.836 & 0.194 \\
Fund Ratio Square & 0.559 & 0.709 & 0.879 & 0.737 & 0.328 \\
NOL & 0 & 1 & 1 & 0.575 & 0.495 \\
Market Return & 0.218 & 0.218 & 0.218 & 0.189 & 0.0619 \\
FVPA (S'm) & 58.78 & 297.8 & 1200 & 1745 & 4187 \\
PBO (S'm) & 80.1 & 350.4 & 1351 & 1980 & 4674 \\
Size & 7.061 & 8.159 & 9.514 & 8.128 & 1.917 \\
\hline
\end{tabular}

PANEL B: USA Sample: Post-Period

\begin{tabular}{|l|ccccc|}
\hline & P25 & P50 & P75 & Mean & SD \\
\hline \%Equities & 16.84 & 36 & 52 & 34.82 & 21.56 \\
\%Fixed Income & 31.36 & 42.87 & 58.28 & 45.26 & 22.23 \\
ERR (\%) & 5.202 & 6.250 & 7 & 5.968 & 1.399 \\
SDCF (S'm) & 0.0322 & 0.0625 & 0.128 & 0.343 & 1.211 \\
Market Cap (S'm) & 876.6 & 2,935 & 11,525 & 13,753 & 31,026 \\
Leverage & 0.0813 & 0.251 & 0.365 & 0.254 & 0.189 \\
Horizon & 3.878 & 4.683 & 7.610 & 7.605 & 5.872 \\
Dividends & 0.00140 & 0.00981 & 0.0230 & 0.0173 & 0.0241 \\
Fund Ratio & 0.731 & 0.835 & 0.936 & 0.832 & 0.196 \\
Fund Ratio Square & 0.534 & 0.698 & 0.877 & 0.731 & 0.332 \\
NOL & 0 & 1 & 1 & 0.579 & 0.494 \\
Market Return & -0.118 & -0.118 & -0.118 & -0.0908 & 0.0558 \\
FVPA (S'm) & 60.4 & 272.6 & 1132 & 1648 & 4028 \\
PBO (S'm) & 74.19 & 325.5 & 1289 & 1882 & 4511 \\
Size & 6.776 & 7.985 & 9.352 & 7.951 & 1.971 \\
\hline
\end{tabular}

Notes: All variables are defined in Appendix B. Panel A provides the descriptive statistics for US firms in the pre-ASU 2017-07 period, while panel B provides the descriptive stats for the post period 
Table 3

PANEL A: Canada Sample: Pre-Period

Descriptive Statistics - Canada Sample

\begin{tabular}{|l|ccccc|}
\hline & P25 & P50 & P75 & Mean & SD \\
\hline \%Equities & 31 & 46 & 59.00 & 42.97 & 20.95 \\
\%Fixed Income & 29 & 39 & 50 & 40.73 & 19.55 \\
ERR (\%) & 3.900 & 5.800 & 6.500 & 5.496 & 1.314 \\
SDCF (S'm) & 0.0453 & 0.0930 & 0.161 & 0.537 & 1.835 \\
Market Cap (S'm) & 550.2 & 2,035 & 8,512 & 7,301 & 12,683 \\
Leverage & 0.120 & 0.241 & 0.370 & 0.253 & 0.186 \\
Horizon & 3.550 & 4.003 & 5.078 & 6.043 & 5.102 \\
Dividends & 0.00147 & 0.0117 & 0.0236 & 0.0153 & 0.0173 \\
Fund Ratio & 0.785 & 0.904 & 0.981 & 0.875 & 0.189 \\
Fund Ratio Square & 0.616 & 0.816 & 0.963 & 0.800 & 0.295 \\
NOL & 0 & 1 & 1 & 0.590 & 0.494 \\
Market Return & 0.218 & 0.218 & 0.218 & 0.193 & 0.0657 \\
FVPA (S'm) & 39.07 & 172.2 & 1275 & 1538 & 3196 \\
PBO (S'm) & 43.75 & 206.7 & 1455 & 1617 & 3243 \\
Size & 6.310 & 7.618 & 9.049 & 7.413 & 2.090 \\
\hline
\end{tabular}

PANEL B: Canada Sample: Post-Period

\begin{tabular}{|l|ccccc|}
\hline & P25 & P50 & P75 & Mean & SD \\
\hline \%Equities & 25.82 & 41 & 56 & 39.14 & 20.83 \\
\%Fixed Income & 31 & 42 & 55.10 & 43.24 & 20.02 \\
ERR (\%) & 4 & 5.600 & 6.500 & 5.305 & 1.398 \\
SDCF (S'm) & 0.0486 & 0.0919 & 0.167 & 0.575 & 1.947 \\
Market Cap (S'm) & 389.6 & 1,233 & 6,337 & 6,217 & 11,859 \\
Leverage & 0.120 & 0.250 & 0.379 & 0.262 & 0.191 \\
Horizon & 3.476 & 4.034 & 5.147 & 6.240 & 5.302 \\
Dividends & 0.00195 & 0.0118 & 0.0238 & 0.0180 & 0.0272 \\
Fund Ratio & 0.814 & 0.898 & 0.976 & 0.864 & 0.188 \\
Fund Ratio Square & 0.662 & 0.807 & 0.952 & 0.781 & 0.290 \\
NOL & 0 & 1 & 1 & 0.604 & 0.491 \\
Market Return & -0.118 & -0.118 & -0.118 & -0.0930 & 0.0595 \\
FVPA (S'm) & 33.69 & 150.4 & 1119 & 1395 & 2891 \\
PBO (S'm) & 39.78 & 183.1 & 1224 & 1486 & 2963 \\
Size & 5.965 & 7.117 & 8.754 & 7.128 & 2.166 \\
\hline
\end{tabular}

Notes: All variables are defined in Appendix B. Panel A provides the descriptive statistics for Canadian firms in the pre-ASU 2017-07 period, while panel B provides the descriptive stats for the post period 
Table 4

Difference-In-Difference Regressions of \% EQUITIES or \% Fixed Income Using US Firms (Treatment) and Canadian Firms (Control)

\section{$\%$ EQUITIES $(\%$ Fixed Income $)=\beta 0+\beta 1$ POST $+\beta 2$ US $+\beta 3$ US * POST $+\Sigma$ CONTROLS}

\begin{tabular}{|c|c|c|c|c|}
\hline \multirow{2}{*}{$\begin{array}{l}\text { DEPENDENT } \\
\text { VARIABLE }\end{array}$} & \multicolumn{2}{|c|}{ Panel A: No Entropy Balancing } & \multicolumn{2}{|c|}{ Panel B: Entropy Balancing } \\
\hline & $\begin{array}{c}\text { \%Equities } \\
\text { (1) }\end{array}$ & $\begin{array}{c}\% \text { Fixed Income } \\
\text { (2) }\end{array}$ & $\begin{array}{c}\text { \%Equities } \\
\text { (3) }\end{array}$ & $\begin{array}{c}\text { \%Fixed Income } \\
(4)\end{array}$ \\
\hline Post & $\begin{array}{c}-3.066 * * * \\
(0.998)\end{array}$ & $\begin{array}{c}3.359 * * * \\
(1.157)\end{array}$ & $\begin{array}{c}-3.187 * * * \\
(1.162)\end{array}$ & $\begin{array}{l}3.227 * * \\
(1.305)\end{array}$ \\
\hline US X Post & $\begin{array}{c}-1.583 * * \\
(0.764)\end{array}$ & $\begin{array}{c}2.163 * * * \\
(0.817)\end{array}$ & $\begin{array}{c}-2.197 * * \\
(0.867)\end{array}$ & $\begin{array}{c}2.595 * * * \\
(0.867)\end{array}$ \\
\hline Size & $\begin{array}{c}0.840 \\
(1.075)\end{array}$ & $\begin{array}{l}-1.016 \\
(1.044)\end{array}$ & $\begin{array}{c}2.163 * * \\
(1.044)\end{array}$ & $\begin{array}{l}-1.893^{*} \\
(1.064)\end{array}$ \\
\hline Leverage & $\begin{array}{c}5.599 \\
(4.177)\end{array}$ & $\begin{array}{l}-4.216 \\
(5.858)\end{array}$ & $\begin{array}{c}0.586 \\
(6.056)\end{array}$ & $\begin{array}{l}-3.172 \\
(7.584)\end{array}$ \\
\hline SDCF & $\begin{array}{c}0.100 \\
(0.418)\end{array}$ & $\begin{array}{c}0.213 \\
(0.595)\end{array}$ & $\begin{array}{l}-0.115 \\
(0.419)\end{array}$ & $\begin{array}{c}0.226 \\
(0.598)\end{array}$ \\
\hline NOL & $\begin{array}{c}2.610 * * * \\
(0.873)\end{array}$ & $\begin{array}{l}-2.284^{*} \\
(1.174)\end{array}$ & $\begin{array}{c}1.292 \\
(1.024)\end{array}$ & $\begin{array}{l}-1.341 \\
(1.004)\end{array}$ \\
\hline Fund Ratio & $\begin{array}{l}-34.50 \\
(43.12)\end{array}$ & $\begin{array}{c}47.25 \\
(56.69)\end{array}$ & $\begin{array}{l}-75.64 \\
(53.66)\end{array}$ & $\begin{array}{l}27.40 \\
(60.97)\end{array}$ \\
\hline Fund Ratio Square & $\begin{array}{c}1.091 \\
(25.52)\end{array}$ & $\begin{array}{l}-2.765 \\
(32.59)\end{array}$ & $\begin{array}{c}19.79 \\
(29.23)\end{array}$ & $\begin{array}{l}11.50 \\
(35.12)\end{array}$ \\
\hline Horizon & $\begin{array}{l}-0.0598 \\
(0.214)\end{array}$ & $\begin{array}{c}0.395 \\
(0.383)\end{array}$ & $\begin{array}{l}-0.0268 \\
(0.151)\end{array}$ & $\begin{array}{c}0.316 \\
(0.231)\end{array}$ \\
\hline Dividends & $\begin{array}{l}4.110 \\
(20.59)\end{array}$ & $\begin{array}{l}21.16 \\
(28.66)\end{array}$ & $\begin{array}{l}-12.26 \\
(23.36)\end{array}$ & $\begin{array}{l}37.01 \\
(26.19)\end{array}$ \\
\hline Market Return & $\begin{array}{l}3.405 \\
(2.617)\end{array}$ & $\begin{array}{c}2.651 \\
(3.209)\end{array}$ & $\begin{array}{l}0.0639 \\
(3.033)\end{array}$ & $\begin{array}{c}4.280 \\
(3.412)\end{array}$ \\
\hline Constant & $\begin{array}{c}59.09 * * * \\
(19.46)\end{array}$ & $\begin{array}{l}9.470 \\
(25.51)\end{array}$ & $\begin{array}{c}72.10 * * * \\
(24.68)\end{array}$ & $\begin{array}{l}22.13 \\
(27.94)\end{array}$ \\
\hline Observations & 1,770 & 1,770 & 1,770 & 1,770 \\
\hline R-squared & 0.243 & 0.171 & 0.241 & 0.168 \\
\hline Number of firms & 885 & 885 & 885 & 885 \\
\hline Cluster SE by firm & YES & YES & YES & YES \\
\hline Firm FE & YES & YES & YES & YES \\
\hline
\end{tabular}

Notes: All variables are defined in Appendix B. Standard errors are clustered by firm.

$*, * *, * * *$ Denote statistical significance at 10 percent, 5 percent, and 1 percent levels, respectively (two-tailed tests).

Panel A presents the results of the difference-in-difference specification without entropy balancing, while panel B presents the results with entropy balancing. The details of entropy balancing are presented in Appendix C. Post is an indicator variable that is set to 1 for fiscal years ending on or after Dec 15th, 2018, and set to 0 for fiscal years ending Dec 15 th, 2017 to Dec 14 th 2018. The variable of interest US X Post is an interactive term. Due to firm fixed-effects, the coefficient of US is suppressed. 


\section{Table 5}

Difference-In-Difference Regressions of \%EQUITIES Using US Firms (Treatment) and Canadian Firms (Control)

$\%$ EQUITIES $=\beta 0+\beta 1$ POST $+\beta 2$ US $+\beta 3$ US $*$ POST $+\Sigma$ CONTROLS

PANEL A:

High values of expected return/other pension costs
PANEL B:

Low values of expected return/other pension costs

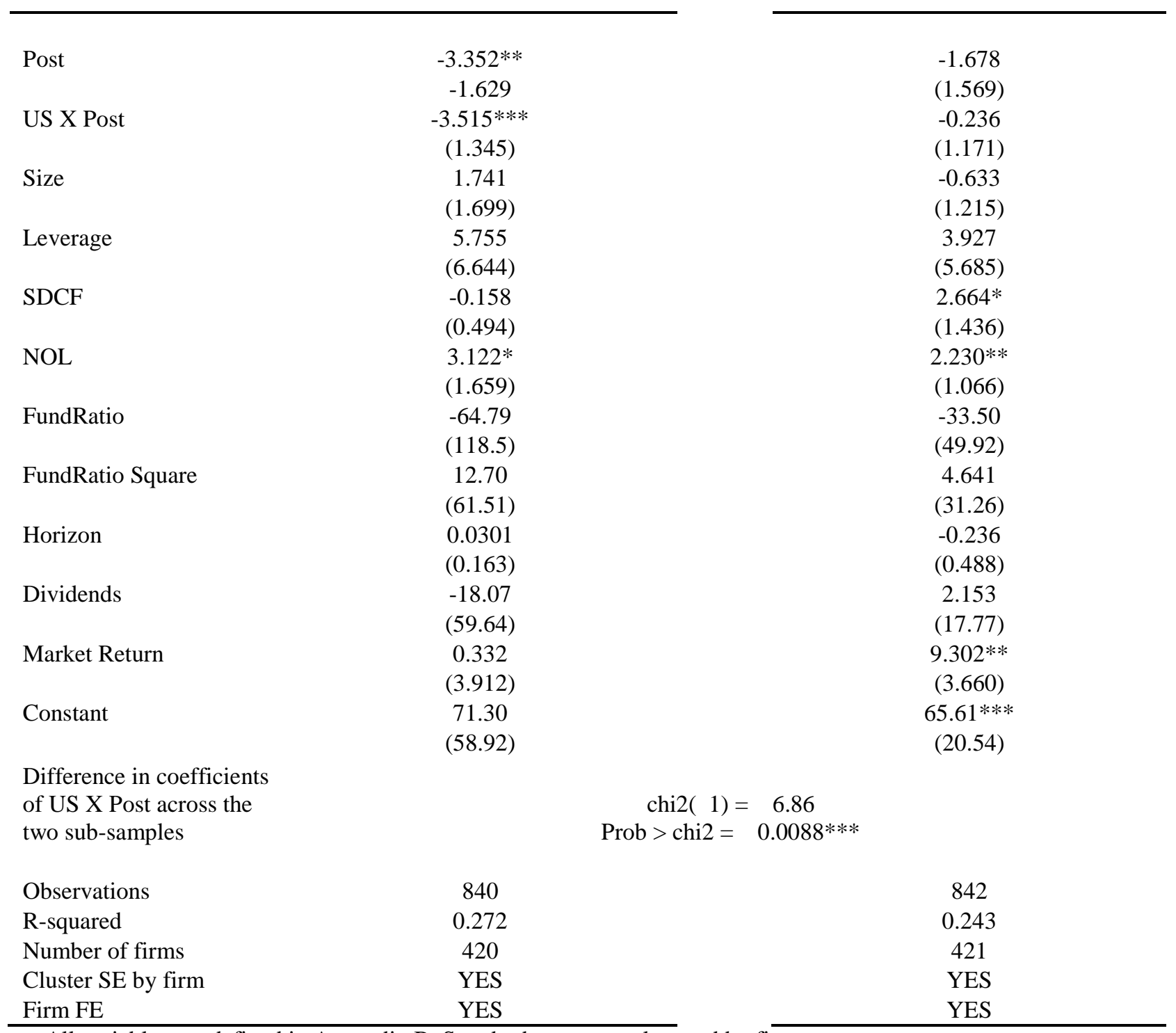

Notes: All variables are defined in Appendix B. Standard errors are clustered by firm.

*, **, *** Denote statistical significance at 10 percent, 5 percent, and 1 percent levels, respectively (two-tailed tests).

Panel A contains firms with high values (i.e. above median) of the ratio of expected return to all other components of pension costs in the year immediately before ASU 2017-07, and panel B contains firms with low values (i.e. below median) of the same ratio in the year immediately before ASU 2017-07. If expected returns or any of the other costs are missing, this ratio is left undefined. We define the median values of this ratio separately for Canadian and US firms in the year immediately before ASU 2017-07. Post is an indicator variable that is set to 1 for fiscal years ending on or after Dec 15th, 2018 and set to 0 for fiscal years ending Dec 15th, 2017 to Dec 14th 2018. The variable of interest US X Post is an interactive term. Due to firm fixedeffects, the coefficient of US is suppressed. 


\section{Table 6}

Difference-In-Difference Regressions of \%EQUITIES Using US Firms (Treatment) and Canadian Firms (Control)

$\%$ EQUITIES $=\beta 0+\beta 1$ POST $+\beta 2$ US $+\beta 3$ US $*$ POST $+\Sigma$ CONTROLS

PANEL A:

High values of fvpa/operating

income

\begin{tabular}{|c|c|c|c|}
\hline Post & $\begin{array}{l}-1.484 \\
(1.194)\end{array}$ & & $\begin{array}{c}-4.243 * * \\
(1.662)\end{array}$ \\
\hline US X Post & $\begin{array}{c}-2.370 * * * \\
(0.780)\end{array}$ & & $\begin{array}{l}-0.729 \\
(1.382)\end{array}$ \\
\hline Size & $\begin{array}{c}0.359 \\
(1.552)\end{array}$ & & $\begin{array}{l}-0.123 \\
(2.003)\end{array}$ \\
\hline Leverage & $\begin{array}{l}2.340 \\
(3.414)\end{array}$ & & $\begin{array}{l}7.196 \\
(10.28)\end{array}$ \\
\hline SDCF & $\begin{array}{l}-0.448 \\
(0.457)\end{array}$ & & $\begin{array}{l}1.769^{*} \\
(0.907)\end{array}$ \\
\hline NOL & $\begin{array}{l}1.942 * * \\
(0.946)\end{array}$ & & $\begin{array}{l}2.518^{*} \\
(1.421)\end{array}$ \\
\hline FundRatio & $\begin{array}{l}-81.49 \\
(70.88)\end{array}$ & & $\begin{array}{l}-26.49 \\
(53.76)\end{array}$ \\
\hline FundRatio Square & $\begin{array}{c}37.62 \\
(42.38)\end{array}$ & & $\begin{array}{l}-7.722 \\
(31.90)\end{array}$ \\
\hline Horizon & $\begin{array}{c}0.100 \\
(0.0829)\end{array}$ & & $\begin{array}{l}-0.281 \\
(0.369)\end{array}$ \\
\hline Dividends & $\begin{array}{l}-3.516 \\
(18.84)\end{array}$ & & $\begin{array}{l}10.65 \\
(36.99)\end{array}$ \\
\hline Market Return & $\begin{array}{c}3.947 \\
(3.180)\end{array}$ & & $\begin{array}{c}5.191 \\
(4.802)\end{array}$ \\
\hline Constant & $\begin{array}{c}75.70 * * * \\
(28.41)\end{array}$ & & $\begin{array}{l}67.15^{* *} \\
(29.05)\end{array}$ \\
\hline $\begin{array}{l}\text { Difference in coefficients } \\
\text { of US X Post }\end{array}$ & & $\begin{array}{r}\operatorname{chi} 2(1)= \\
\text { Prob }>\operatorname{chi} 2=\end{array}$ & $\begin{array}{l}2.17 \\
0.1407\end{array}$ \\
\hline Observations & 850 & & 852 \\
\hline R-squared & 0.303 & & 0.238 \\
\hline Number of firms & 425 & & 426 \\
\hline Cluster SE by firm & YES & & YES \\
\hline Firm FE & YES & & YES \\
\hline
\end{tabular}

PANEL B:

Low values of fvpa/operating income

$-4.243 * *$

$(1.382)$

$-0.123$

(2.003)

7.196

$(10.28)$

$1.769^{*}$

(0.907)

2.518*

(1.421)

$-26.49$

(53.76)

$-7.722$

(31.90)

$-0.281$

(36.99)

5.19

(4.802)

6.15**

Notes: All variables are defined in Appendix B. Standard errors are clustered by firm.

$*, * *, * * *$ Denote statistical significance at 10 percent, 5 percent, and 1 percent levels, respectively (two-tailed tests).

Panel A contains firms with high values (i.e. above median) of the ratio of fair value of plan assets to operating income in the year immediately before ASU 2017-07, and panel B contains firms with low values (i.e. below median) of this ratio in the year immediately before ASU 2017-07. If operating income is negative, we use the average operating income in the past three years ending in the current year. If the three-year average operating income is negative, this variable is undefined and the observation is removed from this analysis. We define the median values of this ratio separately for Canadian and US firms in the year immediately before ASU 2017-07. Post is an indicator variable that is set to 1 for fiscal years ending on or after Dec 15th, 2018 and set to 0 for fiscal years ending Dec 15th, 2017 to Dec 14th 2018. The variable of interest US X Post is an interactive term. Due to firm fixed-effects, the coefficient of US is suppressed. 


\section{Table 7}

\section{Difference-In-Difference Regressions of \%EQUITIES Using US Firms (Treatment) and Canadian Firms (Control)}

$\%$ EQUITIES $=\beta 0+\beta 1$ POST $+\beta 2$ US $+\beta 3$ US $*$ POST $+\Sigma$ CONTROLS

PANEL A:

Analyst estimate available for operating profit
PANEL B:

Analyst estimate not available for operating profit

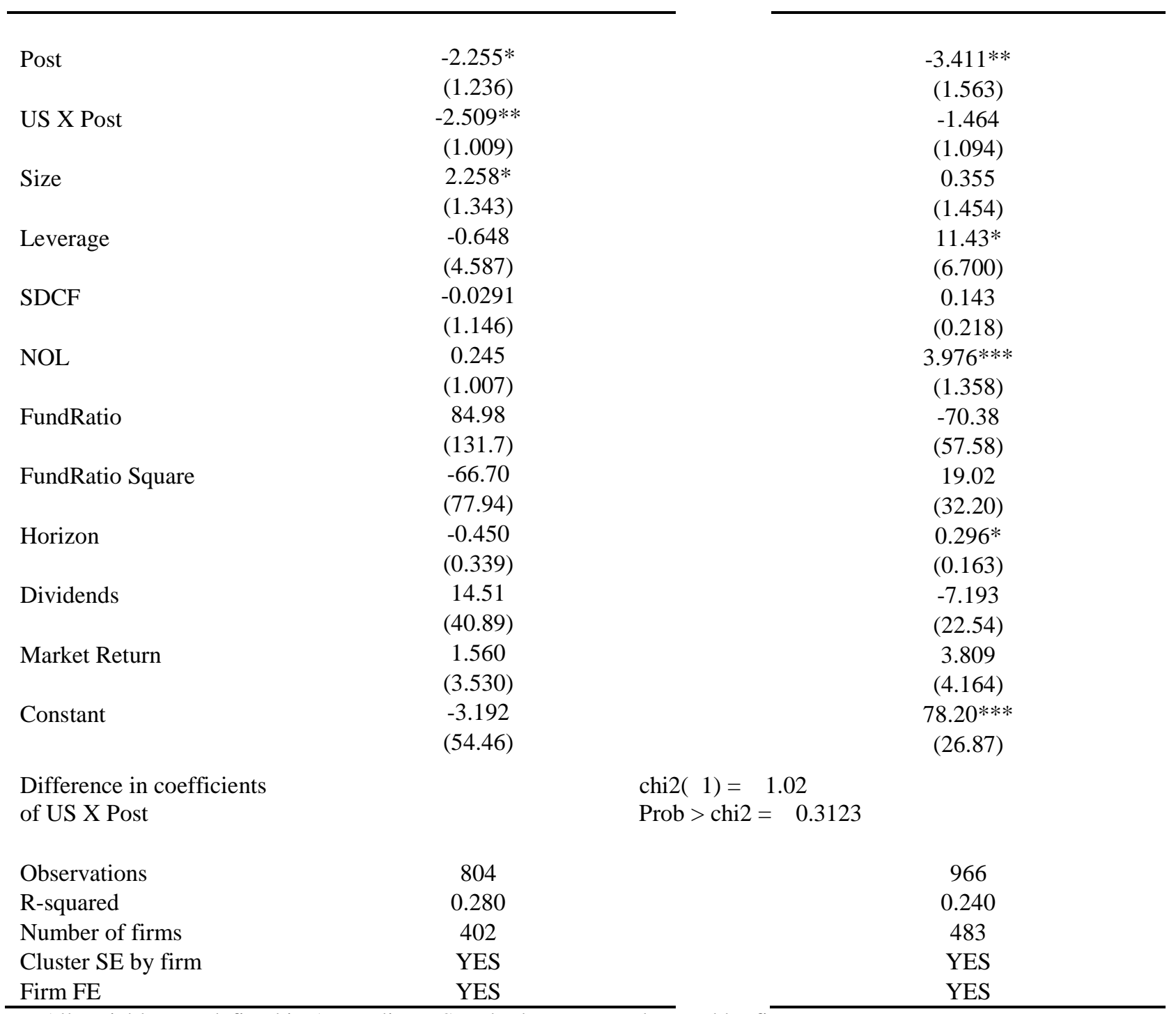

Notes: All variables are defined in Appendix B. Standard errors are clustered by firm.

$*, * *, * * *$ Denote statistical significance at 10 percent, 5 percent, and 1 percent levels, respectively (two-tailed tests).

Panel A contains firms that have at least one analyst estimate of operating profit in the year immediately before ASU 2017-07, and panel B contains firms with no analyst estimate of operating profit in the year immediately before ASU 2017-07. Firms that are not present in the IBES database are treated as not having any analyst estimate of operating profit, i.e. they are included in the Panel B sub-sample. Post is an indicator variable that is set to 1 for fiscal years ending on or after Dec 15th, 2018 and set to 0 for fiscal years ending Dec 15th, 2017 to Dec 14th 2018. The variable of interest US X Post is an interactive term. Due to firm fixed-effects, the coefficient of US is suppressed. 


\section{Table 8}

Difference-In-Difference Regressions of \%EQUITIES Using US Firms (Treatment) and Canadian Firms (Control)

$\%$ EQUITIES $=\beta 0+\beta 1$ POST $+\beta 2$ US $+\beta 3$ US $*$ POST $+\Sigma$ CONTROLS

PANEL A:

High value relevance of operating income

\begin{tabular}{|c|c|c|}
\hline & $\begin{array}{l}\text { PANEL A: } \\
\text { High value relevance of operating } \\
\text { income }\end{array}$ & $\begin{array}{l}\text { PANEL B: } \\
\text { Low value relevance of operating } \\
\text { income }\end{array}$ \\
\hline Post & $\begin{array}{l}-2.154 \\
(1.422)\end{array}$ & $\begin{array}{c}-4.148 * * * \\
(1.515)\end{array}$ \\
\hline US X Post & $\begin{array}{c}-2.610 * * \\
(1.081)\end{array}$ & $\begin{array}{l}-0.694 \\
(1.127)\end{array}$ \\
\hline Size & $\begin{array}{c}2.136 \\
(1.823)\end{array}$ & $\begin{array}{l}-0.474 \\
(1.158)\end{array}$ \\
\hline Leverage & $\begin{array}{l}15.46^{*} \\
(8.186)\end{array}$ & $\begin{array}{c}1.937 \\
(4.160)\end{array}$ \\
\hline SDCF & $\begin{array}{c}0.880 \\
(0.861)\end{array}$ & $\begin{array}{l}-0.295 \\
(0.422)\end{array}$ \\
\hline NOL & $\begin{array}{c}3.115^{* * *} \\
(1.053)\end{array}$ & $\begin{array}{c}2.023 \\
(1.447)\end{array}$ \\
\hline FundRatio & $\begin{array}{l}-9.476 \\
(55.09)\end{array}$ & $\begin{array}{c}-91.27 * * \\
(45.29)\end{array}$ \\
\hline FundRatio Square & $\begin{array}{l}-7.387 \\
(33.94)\end{array}$ & $\begin{array}{l}27.11 \\
(25.39)\end{array}$ \\
\hline Horizon & $\begin{array}{c}0.235 \\
(0.181)\end{array}$ & $\begin{array}{l}-0.324 \\
(0.385)\end{array}$ \\
\hline Dividends & $\begin{array}{c}1.904 \\
(31.74)\end{array}$ & $\begin{array}{l}3.684 \\
(25.27)\end{array}$ \\
\hline Market Return & $\begin{array}{c}3.540 \\
(3.926)\end{array}$ & $\begin{array}{l}2.864 \\
(3.537)\end{array}$ \\
\hline Constant & $\begin{array}{l}27.53 \\
(25.57)\end{array}$ & $\begin{array}{c}102.9 * * * \\
(22.23)\end{array}$ \\
\hline $\begin{array}{l}\text { Difference in coefficients } \\
\text { of US X Post }\end{array}$ & & $\begin{array}{l}5 * \\
0.0806\end{array}$ \\
\hline Observations & 884 & 886 \\
\hline R-squared & 0.214 & 0.313 \\
\hline Number of firms & 442 & 443 \\
\hline Cluster SE by firm & YES & YES \\
\hline Firm FE & YES & YES \\
\hline
\end{tabular}

PANEL B:

Notes: All variables are defined in Appendix B. Standard errors are clustered by firm.

*, **, *** Denote statistical significance at 10 percent, 5 percent, and 1 percent levels, respectively (two-tailed tests).

Panel A contains firms with high (i.e. above median) value relevance of operating income as compared to net income, and panel $\mathrm{B}$ contains firms with low (i.e. below median) value relevance of operating income as compared to net income. Value relevance of operating income is calculated as the ratio of R-square of operating income regression to the R-square of net income regression using 16 quarters of data just prior to the beginning of the post-period.

We define the median values of this ratio separately for Canadian and US firms in the period immediately before ASU 201707. Post is an indicator variable that is set to 1 for fiscal years ending on or after Dec 15th, 2018 and set to 0 for fiscal years ending Dec 15th, 2017 to Dec 14th 2018. The variable of interest US X Post is an interactive term. Due to firm fixed-effects, the coefficient of US is suppressed. 


\section{Figure 1}

\section{Graphical Representation of Mean and Median Values of \%Equities for US and Canadian firms}
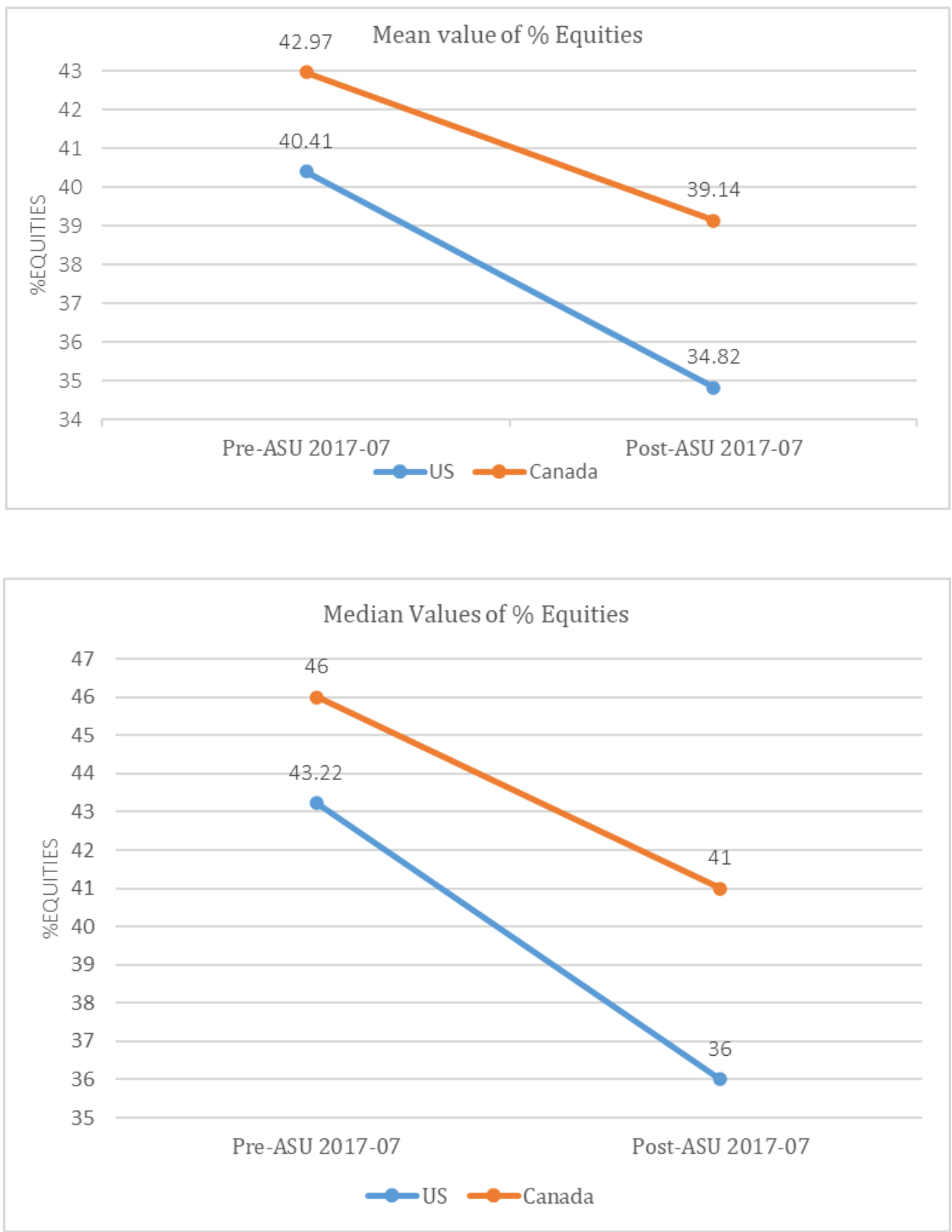

The figure at the top depicts a graphical representation of the change in mean values of \%Equities between the preand post-ASU 2017-07 period for US (treatment) and Canadian (control) firms. The figure at the bottom depicts a graphical representation of the change in median values of \%Equities between the pre- and post-ASU 2017-07 period for US (treatment) and Canadian (control) firms. 